\title{
Bacterial Metabolism in Wastewater Treatment Systems
}

Claudia Gallert and Josef Winter

\section{1 \\ Introduction}

Water that has been used by people and is disposed into a receiving water body with altered physical and/or chemical parameters is defined as wastewater. If only the physical parameters of the water were changed, e.g., resulting in an elevated temperature after use as a coolant, treatment before final disposal into a surface water may require only cooling close to its initial temperature. If the water, however, has been contaminated with soluble or insoluble organic or inorganic material, a combination of mechanical, chemical, and/or biological purification procedures may be required to protect the environment from periodic or permanent pollution or damage. For this reason, legislation in industrialized and in many developing countries has reinforced environmental laws that regulate the maximum allowed residual concentrations of carbon, nitrogen, and phosphorous compounds in purified wastewater, before it is disposed into a river or into any other receiving water body However, enforcement of these laws is not always very strict. Enforcement seems to be related to the economy of the country and thus differs significantly between wealthy industrialized and poor developing countries. In this chapter basic processes for biological treatment of waste or wastewater to eliminate organic and inorganic pollutants are summarized.

\section{2}

Decomposition of Organic Carbon Compounds in Natural and Manmade Ecosystems

Catabolic processes of microorganisms, algae, yeasts, and lower fungi are the main pathways for total or at least partial mineralization/decomposition of bioorganic and organic compounds in natural or manmade environments. Most of this material is derived directly or indirectly from recent plant or animal biomass. It originates from carbon dioxide fixation via photosynthesis ( $\rightarrow$ plant biomass), from plants that served as animal feed ( $\rightarrow$ detritus, feces, urine, etc.), or from fossil fuels or biologi- 
cally or geochemically transformed biomass ( $\rightarrow$ peat, coal, oil, natural gas). Even the carbon portion of some xenobiotics can be tracked back to a biological origin, i.e., if these substances were produced from oil, natural gas, or coal. Only because the mineralization of carbonaceous material from decaying plant and animal biomass in nature under anaerobic conditions with a shortage of water was incomplete, did the formation of fossil oil, natural gas, and coal deposits from biomass occur through biological and/or geochemical transformations. The fossil carbon of natural gas, coal, and oil enters the atmospheric $\mathrm{CO}_{2}$ cycle again as soon as these compounds are incinerated as fuels or used for energy generation in industry or private households.

Biological degradation of recent biomass and of organic chemicals during solid waste or wastewater treatment proceeds either in the presence of molecular oxygen by respiration, under anoxic conditions by denitrification, or under anaerobic conditions by methanogenesis or sulfidogenesis. Respiration of soluble organic compounds or of extracellularly solubilized biopolymers such as carbohydrates, proteins, fats, or lipids in activated sludge systems leads to the formation of carbon dioxide, water, and a significant amount of surplus sludge. Some ammonia and $\mathrm{H}_{2} \mathrm{~S}$ may be formed during degradation of sulfur-containing amino acids or heterocyclic compounds. Oxygen must either be supplied by aeration or by injection of pure oxygen. The two process variant for oxygen supply differ mainly in their capacity for oxygen transfer and the stripping efficiency for carbon dioxide from respiration. Stripping of carbon dioxide is necessary to prevent a drop in $\mathrm{pH}$ and to remove heat energy. Respiration in the denitrification process with chemically bound oxygen supplied in the form of nitrate or nitrite abundantly yields dinitrogen. However, some nitrate escapes the reduction to dinitrogen in wastewater treatment plants and contributes about $2 \%$ of the total $\mathrm{N}_{2} \mathrm{O}$ emissions in Germany (Schön et al., 1994). Denitrifiers are aerobic organisms that switch their respiratory metabolism to the utilization of nitrate or nitrite as terminal electron acceptors, if grown under anoxic conditions. Only if the nitrate in the bulk mass has been used completely does the redox potential become low enough for growth of strictly anaerobic organisms, such as methanogens or sulfate reducers. If anaerobic zones are allowed to form in sludge flocs of an activated sludge system, e.g., by limitation of the oxygen supply, methanogens and sulfate reducers may develop in the center of sludge flocs and form traces of methane and hydrogen sulfide, found in the off-gas.

Under strictly anaerobic conditions, soluble carbon compounds of wastes and wastewater are degraded stepwise to methane, $\mathrm{CO}_{2}, \mathrm{NH}_{3}$, and $\mathrm{H}_{2} \mathrm{~S}$ via a syntrophic interaction of fermentative and acetogenic bacteria with methanogens or sulfate reducers. The complete methanogenic degradation of biopolymers or monomers via hydrolysis/fermentation, acetogenesis, and methanogenesis can proceed only at a low $\mathrm{H}_{2}$ partial pressure, which is maintained mainly by interspecies hydrogen transfer. Interspecies hydrogen transfer is facilitated when acetogens and hydrogenolytic methanogenic bacteria are arranged in proximity in flocs or in a biofilm within short diffusion distances. The reducing equivalents for carbon dioxide reduction to methane or sulfate reduction to sulfide are derived from the fermentative metabolism, e.g., of clostridia or Eubacterium sp., from $\beta$ oxidation of fatty acids, or the ox- 
idation of alcohols. Methane and $\mathrm{CO}_{2}$ are the main products in anaerobic environments where sulfate is absent, but sulfide and $\mathrm{CO}_{2}$ are the main products if sulfate is present.

\subsection{1}

\section{Basic Biology, Mass, and Energy Balance of Aerobic Biopolymer Degradation}

To make soluble and insoluble biopolymers - mainly carbohydrates, proteins, and lipids - accessible for respiration by bacteria, the macromolecules must be hydrolyzed by exoenzymes, which often are produced and excreted only after contact with respective inductors. The exoenzymes adsorb to the biopolymers and hydrolyze them to monomers or at least to oligomers. Only soluble, low molecular weight compounds (e.g., sugars, disaccharides, amino acids, oligopeptides, glycerol, fatty acids) can be taken up by microorganisms and be metabolized for energy production and cell multiplication.

Once taken up, degradation via glycolysis (sugars, disaccharides, glycerol), hydrolysis and deamination (amino acids, oligopeptides), or hydrolysis and $\beta$ oxidation (phospholipids, long-chain fatty acids) proceeds in the cells. Metabolism of almost all organic compounds leads to the formation of acetyl-CoA as the central intermediate, which is used for biosyntheses, excreted as acetate, or oxidized to $\mathrm{CO}_{2}$ and reducing equivalents in the tricarboxylic acid (TCA) cycle. The reducing equivalents are respired with molecular oxygen in the respiration chain. The energy of a maximum of only $2 \mathrm{~mol}$ of anhydridic phosphate bonds of ATP is conserved during glycolysis of $1 \mathrm{~mol}$ of glucose through substrate chain phosphorylation. An additional $2 \mathrm{~mol}$ of ATP are formed during oxidation of $2 \mathrm{~mol}$ of acetate in the TCA cycle, whereas 34 mol ATP are formed by electron transport chain phosphorylation with oxygen as the terminal electron acceptor. During oxygen respiration, reducing equivalents react with molecular oxygen in a controlled combustion reaction.

When carbohydrates are respired by aerobic bacteria, about one third of the initial energy content is lost as heat, and two thirds are conserved biochemically in 38 phosphoanhydride bonds of ATP. In activated sludge reactors or in wastewater treatment ponds that are not loaded with highly concentrated wastewater, wall irradiation and heat losses with the off-gas stream of aeration into the atmosphere prevent self-heating. In activated sludge reactors for treatment of highly concentrated wastewater, however, self-heating up to thermophilic temperatures may occur if the wastewater is warm in the beginning, the hydraulic retention time for biological treatment is short (short aeration time), and the air or oxygen stream for aeration is restricted so as to supply just sufficient oxygen for complete oxidation of the pollutants (small aeration volume).

The conserved energy in the terminal phosphoanhydride bond of ATP, formed during substrate chain and oxidative phosphorylation by proliferating bacteria is partially used for maintenance metabolism and partially for cell multiplication. Partitioning between both is not constant, but depends on the nutritional state. In highly loaded activated sludge reactors with a surplus or at least a non-growth-limiting substrate supply, approximately $50 \%$ of the substrate is respired in the energy me- 
tabolism of the cells and 50\% serves as a carbon source for cell growth (Table 1.1). The biochemically conserved energy must be dissipated to be used for the maintenance metabolism of existing cells and cell growth.

If the substrate supply is growth-limiting, e.g., in a low-loaded aerobic treatment system, a higher proportion of ATP is consumed for maintenance, representing the energy proportion that bacteria must spend for non-growth-associated cell survival metabolism, and less energy is available for growth. Overall, more of the substrate carbon is respired, and the ratio of respiration products to surplus sludge formed is higher, e.g., around 70\%: 30\% (Table 1.1). In a trickling filter system, an even higher proportion of the substrate seems to be respired. This might be due to protozoa grazing off part of the biofilm.

For comparison, Table 1.1 also summarizes carbon dissipation in anaerobic methanogenic degradation. Only about $5 \%$ of the fermentable substrate is used for cell growth (surplus sludge formation) in anaerobic reactors, whereas $95 \%$ is converted to methane and $\mathrm{CO}_{2}$, and most of the energy of the substrates is conserved in the fermentation products.

\subsubsection{Mass and Energy Balance for Aerobic Glucose Respiration and Sewage Sludge Stabilization}

In most textbooks of microbiology, respiration of organic matter is explained by Eq. 1, with glucose used as a model substance. Except for an exact reaction stoichiometry of the oxidative metabolism, mass and energy dissipation, if mentioned at all, are not quantified. Both parameters are, however, very important for activated sludge treatment plants. The surplus sludge formed during wastewater stabilization requires further treatment, causes disposal costs, and - in the long run - may be an environmental risk, and heat evolution during unevenly high-loaded aerobic treatment may shift the population toward more thermotolerant or thermophilic species and thus, at least for some time, may decrease the process efficiency.

$$
1 \mathrm{~mol} \mathrm{C}_{6} \mathrm{H}_{12} \mathrm{O}_{6}+6 \mathrm{~mol} \mathrm{O}_{2} \rightarrow 6 \mathrm{~mol} \mathrm{CO}_{2}+6 \mathrm{~mol} \mathrm{H}_{2} \mathrm{O}+\text { heat energy }
$$

Table 1.1 Carbon flow during (A) aerobic degradation in an activated sludge system under (a) saturating and (b) limiting substrate supply and during (B) anaerobic degradation.

(A) Aerobic degradation:

(a) Saturating substrate supply $=$ high-load conditions 1 unit substrate carbon $\rightarrow 0.5$ units $\mathrm{CO}_{2}$ carbon +0.5 units cell carbon

(b) Limiting substrate supply = low-load conditions 1 unit substrate carbon $\rightarrow 0.7$ units $\mathrm{CO}_{2}$ carbon +0.3 units cell carbon

(B) Anaerobic degradation:

1 unit substrate carbon $\rightarrow 0.95$ units $\left(\mathrm{CO}_{2}+\mathrm{CH}_{4}\right)$ carbon +0.05 units cell carbon

\footnotetext{
a Estimated from surplus sludge formation in different wastewater treatment plants.
} 
If $1 \mathrm{~mol}$ of glucose (MW=180 g) is degraded in an activated sludge system at a high BOD loading rate (e.g., $>0.6 \mathrm{~kg} \mathrm{~m}^{-3} \mathrm{~d}^{-1} \mathrm{BOD}$ ), approximately $0.5 \mathrm{~mol}(90 \mathrm{~g})$ is respired to $\mathrm{CO}_{2}$ and water, with consumption of $3 \mathrm{~mol}$ of $\mathrm{O}_{2}(96 \mathrm{~g})$, releasing $19 \mathrm{~mol}$ of ATP (Fig. 1.1). The other $0.5 \mathrm{~mol}$ of glucose $(90 \mathrm{~g})$ is converted to pyruvate by one of three glycolytic pathways, accompanied by the formation of $0.5-1 \mathrm{~mol}$ ATP. Pyruvate or its subsequent metabolic products, e.g., acetate or dicarboxylic acids, are directly used as carbon substrates for cell multiplication and surplus biomass formation. A maximum amount of $20 \mathrm{~mol}$ ATP is thus available for growth and maintenance (Fig. 1.1). At a pH of 7, about $44 \mathrm{~kJ}$ of energy is available for growth per mol of ATP hydrolyzed to ADP and inorganic phosphate (Thauer et al., 1977). For an average molar growth yield of aerobes of $4.75 \mathrm{~g}$ per mol ATP (Lui, 1998), $90 \mathrm{~g}$ biomass can be generated from $180 \mathrm{~g}$ glucose. If the combustion energy per $\mathrm{g}$ of cell dry mass is $22 \mathrm{~kJ}$, about $890 \mathrm{~kJ}$ (2870-980 kJ) is lost as heat during respiration (Fig. 1.1). The energy loss is the sum of heat losses during respiration and cell growth.

At a low BOD loading rate, the proportion of glucose respired in relation to the proportion of glucose fixed as surplus biomass can shift. Up to $0.7 \mathrm{~mol}$ (126 g) of glucose can be oxidized to $\mathrm{CO}_{2}$, requiring $4.2 \mathrm{~mol}$ of oxygen $\left(134.4 \mathrm{~g} \mathrm{O}_{2}\right)$. Thus, for respiration of $1 \mathrm{~mol}$ of glucose, different amounts of oxygen may be consumed, depending on the loading rate of the wastewater treatment system and the different amounts of carbon dioxide and of surplus sludge formed (Fig. 1.1, Table 1.1).

The energy and carbon balance deduced above can be analogously applied to aerobic stabilization of raw sewage sludge. If the initial dry matter content is around $36 \mathrm{~g}$ $\mathrm{L}^{-1}$ (average organic dry matter content of sewage sludge) and if a biodegradability of $50 \%$ within the residence time in the sludge reactor is obtained, about $9 \mathrm{~g} \mathrm{~L}^{-1}$ of new biomass is formed, and thus $27 \mathrm{~g} \mathrm{~L}^{-1}(36-18+9)$ remains in the effluent.

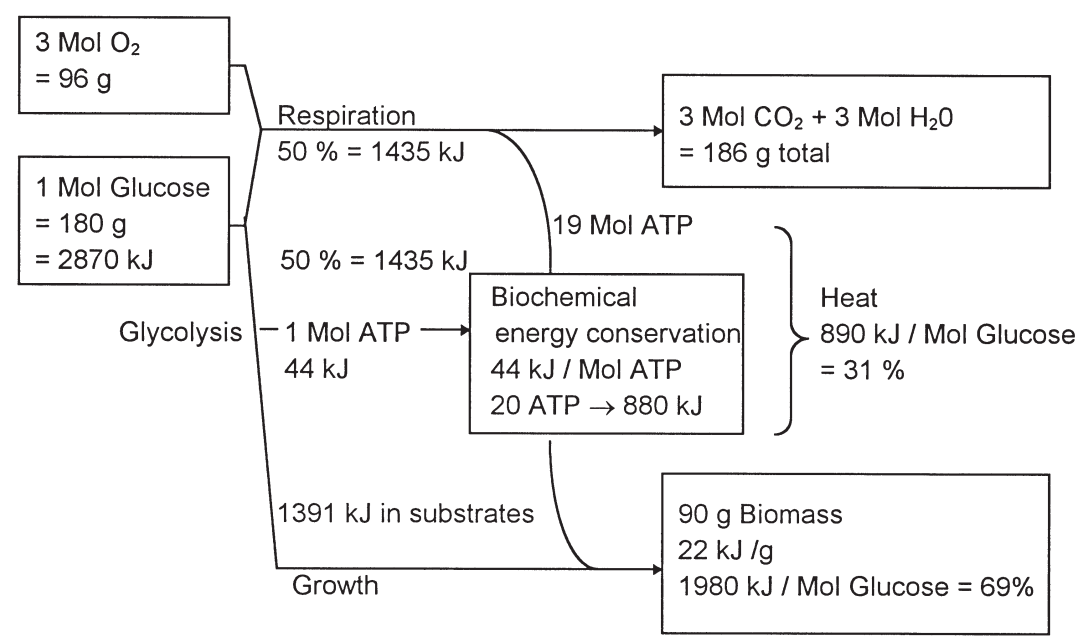

Fig. 1.1 Mass and energy dissipation during glucose respiration at $\mathrm{pH} 7$. 
The released heat energy is approximately $89 \mathrm{~kJ} \mathrm{~L}^{-1}$ of reactor content. To estimate the theoretical temperature rise, this amount of heat energy must be divided by $4.185 \mathrm{~kJ}$ (specific energy requirement for heating $1 \mathrm{~L}$ of $\mathrm{H}_{2} \mathrm{O}$ from $14.5-15.5^{\circ} \mathrm{C}$ ). Thus, by respiration of $18 \mathrm{~g} \mathrm{~L}^{-1}$ organic dry matter, the reactor temperature increases by $21.3^{\circ} \mathrm{C}$ within the residence time required for degradation $(\leq 16 \mathrm{~h})$, provided that no heat energy is lost. A great proportion of the heat energy is, however, transferred via the liquid phase to the aeration gas and stripped out, whereas a smaller proportion is lost through irradiation from the reactor walls. Since air, containing almost $80 \%$ nitrogen, is normally used as an oxygen source in aeration ponds or activated sludge reactors, the heat transfer capacity of the off-gas is high enough to prevent a significant increase in the wastewater temperature. Thus, ambient or at least mesophilic temperatures can be maintained. An increasing temperature of several degrees Celsius would lead to a shift in the population in the reactor and - at least temporarily - would result in reduced process stability, but an only slightly increased temperature of a few degrees Celsius might simply stimulate the metabolic activity of the prevalent mesophilic population. In practice, in activated sewage sludge systems no self-heating is observed because degradability is only about $50 \%$ and complete heat transfer to the atmosphere occurs via the off-gas at a retention time of more than $0.5 \mathrm{~d}$. If, however, wastewater from a dairy plant or a brewery with a similar COD concentration, but with almost $100 \%$ biodegradable constituents, is stabilized with pure oxygen, twice as much heat evolves, leading to a theoretical temperature rise of $57^{\circ} \mathrm{C}$. Self-heating is observed, since there is much less offgas and the heat loss is thus significantly lower. In addition, due to higher reaction rates than with sewage sludge, the heat is generated during a shorter time span (shorter retention time).

\subsubsection{Mass and Energy Balance for Anaerobic Glucose Degradation and Sewage Sludge Stabilization}

For anaerobic wastewater or sludge treatment, oxygen must be excluded to maintain the low redox potential that is required for survival and metabolic activity of the acetogenic, sulfidogenic, and methanogenic populations. Hydrolysis of polymers, uptake of soluble or solubilized carbon sources, and the primary metabolic reactions of glycolysis up to pyruvate and acetate formation seem to proceed identically or at least analogously in aerobic and anaerobic bacteria. Whereas aerobes oxidize acetate in the TCA cycle and respire the reducing equivalents with oxygen, anaerobes, such as Ruminococcus sp., Clostridium sp., or Eubacterium sp., either release molecular hydrogen or transform pyruvate or acetate to highly reduced metabolites, such as lactate, succinate, ethanol, propionate, or $n$-butyrate. For further degradation within the anaerobic food chain, these reduced metabolites must be oxidized anaerobically by acetogenic bacteria. Since the anaerobic oxidation of propionate or $n$-butyrate by acetogenic bacteria is obligately accompanied by hydrogen production but is only slightly exergonic under conditions of a low $\mathrm{H}_{2}$ partial pressure (Bryant, 1979), acetogens can grow only when hydrogen is consumed by hydrogen-scavenging organisms such as methanogens or sulfate reducers. 
During anaerobic degradation of $1 \mathrm{~mol}$ glucose, approximately $95 \%$ of the glucose carbon is used for biogas formation $\left(171 \mathrm{~g}=127.7 \mathrm{~L} \mathrm{CH}_{4}+\mathrm{CO}_{2}\right)$, and only about $5 \%$ of the substrate carbon ( $9 \mathrm{~g}$ ) converted to biomass (Table 1.1). Much less heat energy is released during anaerobic metabolism than during aerobic respiration $(131 \mathrm{~kJ}$ $\mathrm{mol}^{-1}$ versus $890 \mathrm{~kJ} \mathrm{~mol}^{-1}$, respectively), and the biogas contains almost $90 \%$ of the energy of the fermented substrate (Fig. 1.2). Due to the heat energy requirement to warm the wastewater and due to heat losses via irradiation from pipes and reactor walls, heat generation is not nearly sufficient to maintain a constant mesophilic fermentation temperature. For this reason, anaerobic digesters must be heated.

In sewage sludge with $36 \mathrm{~g} \mathrm{~L}^{-1}$ organic dry matter content and $50 \%$ biodegradability, $0.9 \mathrm{~g}$ surplus sludge and $17.1 \mathrm{~g}$ biogas (equivalent to $12.75 \mathrm{~L}$ ) are formed during anaerobic stabilization. Only $13.1 \mathrm{~kJ}$ of heat energy per mol of glucose is released, leading to a self-heating potential of $3.1^{\circ} \mathrm{C}$. Since the heat energy is released only during the hydraulic residence time of the wastewater in the reactor, which is usually more than $10 \mathrm{~d}$ (except for high-rate industrial wastewater treatment, where in special situations the HRT may be shorter than one day), much more heat energy is lost by irradiation via the reactor walls than is required to maintain the temperature. If highly concentrated wastewater streams of the food and beverage industry are stabilized anaerobically at hydraulic retention times of $<1 \mathrm{~d}$ (high space loading), more heat energy is generated within a much shorter time. But even then, process energy from external sources has to be supplied to maintain a temperature of $30-37^{\circ} \mathrm{C}$. Proper insulation of anaerobic reactors can minimize but not replace external heating of the reactor. The methane in the biogas, generated during anaerobic sludge or wastewater stabilization processes, contains about $90 \%$ of the energy of the fermented substrate. Since methane is a climate-relevant gas it may not be emitted into the atmosphere but must be combusted to $\mathrm{CO}_{2}$. Methane from anaerobic reac-

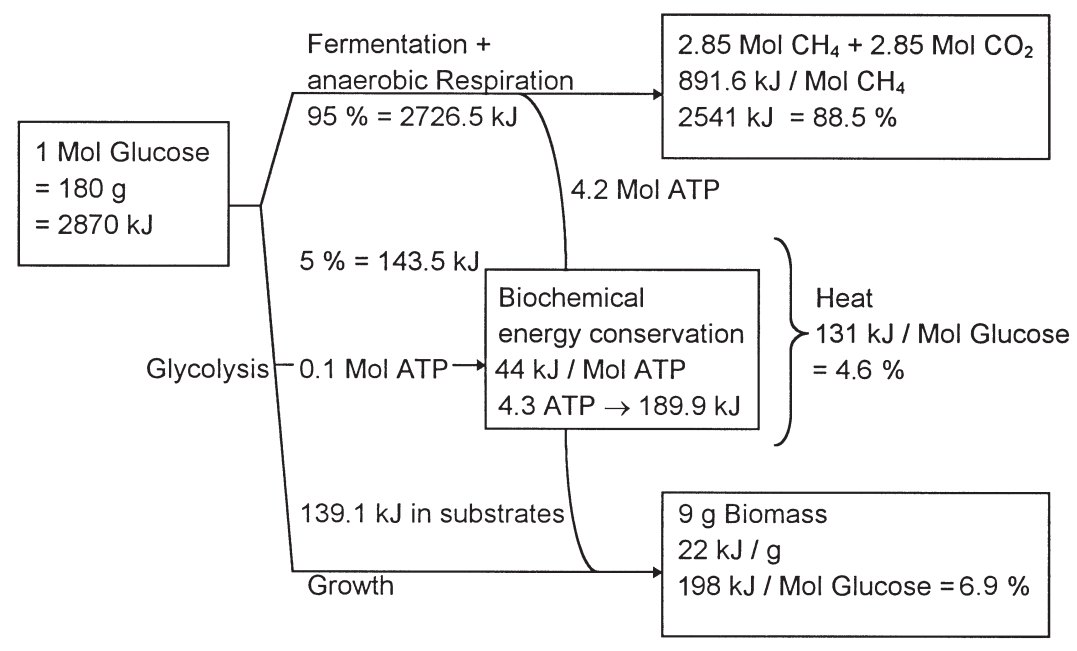

Fig. 1.2 Mass and energy dissipation during anaerobic glucose fermentation at $\mathrm{pH} 7$. 
tors can be used as a fuel for gas engines to generate electricity and/or heat energy (Eq. 2):

$$
\mathrm{CH}_{4}+2 \mathrm{O}_{2} \rightarrow \mathrm{CO}_{2}+2 \mathrm{H}_{2} \mathrm{O}+\text { heat energy }\left(\Delta G^{\circ \prime}=-891.6 \mathrm{~kJ} \mathrm{~mol}^{-1} \mathrm{CH}_{4}\right)
$$

\section{2 .2 \\ General Considerations for the Choice of Aerobic or Anaerobic Wastewater Treatment Systems}

If a producer of wastewater has to decide whether to install an aerobic or an anaerobic waste or wastewater treatment system, several points should be considered:

- Anaerobic treatment in general does not lead to the low pollution standards of $\mathrm{COD}, \mathrm{BOD}_{5}$, or TOC that can be met with aerobic systems and which are required by environmental laws. Anaerobic treatment of wastes and wastewater is often considered a pretreatment process to minimize the oxygen demand and surplus sludge formation in a subsequent aerobic post-treatment stage. Only after a final aerobic treatment can the $\mathrm{COD}, \mathrm{BOD}_{5}$, or TOC concentration limits stated in the environmental laws be met. If limiting concentrations for nitrogen and phosphate also have to be achieved, further treatment steps such as nitrification, denitrification, and biological or chemical phosphate removal, must be considered.

- Highly concentrated wastewater should in general be treated anaerobically, because of the possibility of energy recovery in biogas and the much lower amounts of surplus sludge to be disposed of. For aerobic treatment, a high aeration rate is necessary and much surplus sludge is generated. Aeration causes aerosol formation and eventually requires off-gas purification.

- The efficiency of COD degradation for the bulk mass in concentrated wastewater or sludges (degradability of organic pollutants) generally seems to be about similar in aerobic or anaerobic bacteria. However, the degradation rates may be faster in aerobic treatment procedures than in anaerobic treatment procedures.

- Wastewater with a low concentration of organic pollutants should be treated aerobically due to its higher process stability at low pollutant concentrations, although aerobic treatment is more expensive and more sludge remains for disposal. If mineralized sludge is required, aerobic treatment at a low loading or at prolonged hydraulic retention times is necessary to reinforce respiration of all endogenous reserve material.

- Anaerobic treatment systems are more expensive to construct but less expensive to operate than aerobic treatment systems.

\subsection{3}

\section{Aerobic or Anaerobic Hydrolysis of Biopolymers: Kinetic Aspects}

Hydrolysis of biopolymers and fermentation or respiration of monomers can be catalyzed by strictly anaerobic, facultative anaerobic, and aerobic microorganisms. With some exceptions (e.g., small protein molecules, dextran), biopolymers are insoluble and form fibers (cellulose), grains (starch) or globules (casein after enzymat- 
ic precipitation) or can be melted or emulsified (fat). Henze et al. (1997) reported hydrolysis constants $k_{\mathrm{h}}$ for dissolved organic polymers of 3-20 $\mathrm{d}^{-1}$ under aerobic conditions and of 2-20 $\mathrm{d}^{-1}$ under anaerobic conditions, whereas for suspended solids the hydrolysis constants $k_{\mathrm{h}}$ were 0.6 to $1.4 \mathrm{~d}^{-1}$ under aerobic conditions and 0.3 to $0.7 \mathrm{~d}^{-1}$ under anaerobic conditions. For a kinetic description of hydrolysis and fermentation, a substrate-limited first-order reaction was assumed by Buchauer (1997), who deduced that the temperature-dependent reaction rate for hydrolysis is a little lower than the reaction rate for fermentation of the hydrolysis products. The ratelimiting step is therefore hydrolysis of particles and not fermentation of solubilized material (Buchauer, 1997). Since hydrolysis is catalyzed not only by freely soluble exoenzymes, diluted in the bulk mass of liquid, but to a much higher extent by enzymes that are excreted in the neighborhood of bacterial colonies growing attached to the surface of the particles, the above description of complex fermentation processes is not always valid. Cellulases can be arranged in cellulosomes, which attach to the particles, which in turn serve as carriers until they themselves are solubilized. For this reason, Vavilin et al. (1997) included biomass in their description of the hydrolysis of cellulose, cattle manure, and sludge. Shin and Song (1995) determined the maximum rates of acidification and methanation for several substrates. For hydrolysis of particulate organic matter, the ratio of surface area to particle size is important. They found that for glucose, starch, carboxymethyl cellulose, casein, and food residues from a restaurant, hydrolysis proceeded faster than methanogenesis, whereas for newspaper and leaves hydrolysis was the rate-limiting step.

\subsection{4}

\section{Hydrolysis of Cellulose by Aerobic and Anaerobic Microorganisms: Biological Aspects}

Cellulose and lignin are the main structural compounds of plants. Both substances are the most abundant biopolymers on earth. Cellulose fibers are formed of linear chains of 100-1400 glucose units linked together by $\beta$-1,4-glycosidic bonds. Interand intramolecular hydrogen bonds and van der Waals interactions arrange the highly organized fibrous regions (crystalline region), which alternate with less organized amorphous regions in the cellulose fibers. The fibers are embedded in a matrix of hemicelluloses, pectin, or lignin. The hemicelluloses consist mainly of xylans or glucomannans, which have sidechains of acetyl, gluconuryl, or arabinofuranosyl units. To make cellulose fibers accessible to microorganisms, the hemicellulose, pectin, or lignin matrix must be degraded microbiologically or solubilized chemically. Cellulose degradation in the presence of oxygen in soil or in the absence of oxygen in the rumen of ruminants, in swamps, or in anaerobic digesters is the most important step in mineralization of decaying plant material. Cellulolytic organisms are found among aerobic soil fungi, e.g., within the genera Trichoderma and Phanaerochaete and in anaerobic rumen fungi, e.g. Neocallimastix and Piromyces, and among bacteria, e.g., within the genera Cellulomonas, Pseudomonas, and Thermomonospora (aerobic cellulose degraders) and Clostridium, Fibrobacter, Bacteroides, and Ruminococcus (anaerobic cellulose degraders). For more details on cellulolytic bacteria and the mechanism of cellulose cleavage, please see Coughlan and Mayer (1991). 
Glycosyl hydrolases are involved in cellulose and hemicellulose degradation by cleaving glycosidic bonds between different carbohydrates and between carbohydrates and noncarbohydrates. Endo- and exocellulases - in some organisms organized in cellulosomes - must be excreted into the medium. Cellulases are complex biocatalysts and contain a catalytic site and a substrate-binding site. The presence of a noncatalytic substrate binding site permits tight attachment to the different forms of cellulose substrate and keeps the enzyme close to its cleaving sites. Substrate binding is reversible, which allows the enzyme to 'hike' along the fibers and obtain total solubilization. Many aerobic fungi and some bacteria excrete endoglucanases that hydrolyze the amorphous region of cellulose (degradation within the chain), whereas exoglucanases hydrolyze cellulose from the ends of the glucose chains. Cellobiose is cleaved off by cellobiohydrolases from the nonreducing ends in the amorphous region, and finally the crystalline region is also hydrolyzed.

Cleavage of cellobiose to glucose units by $\beta$-glucosidases is necessary to prevent cellobiose accumulation, which inhibits cellobiohydrolases (Be'guin and Aubert, 1994).

Anaerobic bacteria such as Clostridium thermocellum form a stable enzyme complex, the cellulosome, at the cell surface (Lamed and Bayer, 1988). Cellulosomes are active in degrading crystalline cellulose. The catalytic subunits of a cellulosome, endoglucanases and xylanases, cleave the cellulose fiber into fragments, which are simultaneously degraded further by $\beta$-glucosidases. Cellulosome-like proteins are found also in Ruminococcus sp. and Fibrobacter sp. cultures. The cell-bound enzymes are associated with the capsule or the outer membrane. Other specific adhesions or ligand formations with the cellulose can be facilitated by fimbrial connections, glycosylated epitopes of carbohydrate binding proteins, or the glycocalyx and carbohydrate binding modules (Krause et al., 2003). Some bacteria have not developed a mechanism to adhere to cellulose fibers, but excrete cellulases into the medium. Adsorption of bacteria onto cellulose fibers via cellulosomes offers the advantage of close contact with the substrate, which is hydrolyzed mainly to glucose, which is then taken up and metabolized. Small amounts of cellobiose must be present initially to induce cellulase expression. The contact of bacteria with the solid substrate surface keeps them close to cellobiose and thus keeps cellulase activities high. However, accumulation of hydrolysis products such as glucose repress cellulase activity.

In nature most cellulose is degraded aerobically. Only about $5 \%-10 \%$ is thought to be degraded anaerobically, which may be an underestimate. Since most ecosystems are rich in carbonaceous substances but deficient in nitrogen compounds, many cellulolytic bacteria can also fix dinitrogen. This is advantageous to them and to syntrophic or symbiotic organisms (Leschine, 1995). Other examples of mutual interactions between organisms of an ecosystem are interspecies hydrogen transfer between anaerobes (anaerobic food chain), transfer of growth factors (mycorhizzae, Kefir), and production of fermentable substrates for the partner organisms (bacterial interactions in the rumen).

Hydrolysis of biological structural components such as cellulose, lignin, and other structural or storage polymers (Table 1.2) is difficult. The limiting step of hydrol- 
ysis seems to be liberation of the cleavage products. In contrast to the slow hydrolysis of celluloses, mainly due to lignin encrustation of naturally occurring celluloses, starch can be easily hydrolyzed. The branching and helical structure of starch facilitates hydrolysis (Warren, 1996). Whereas cellulose forms fibers with a large surface covered with lignin, starch forms grains with an unfavorable surface-to-volume ratio for enzymatic cleavage. Thus, although amylases may be present in high concentrations, the hydrolysis rate is limited by the limited access of the enzymes to the substrate.

Whereas cellulose and starch are biodegradable, other carbohydrate-derived cellular compounds are not biodegradable and - after reaction with proteins - form humic acid-like residues by the Maillard reaction.

Table 1.2 Polysaccharides and derivatives occurring in nature.

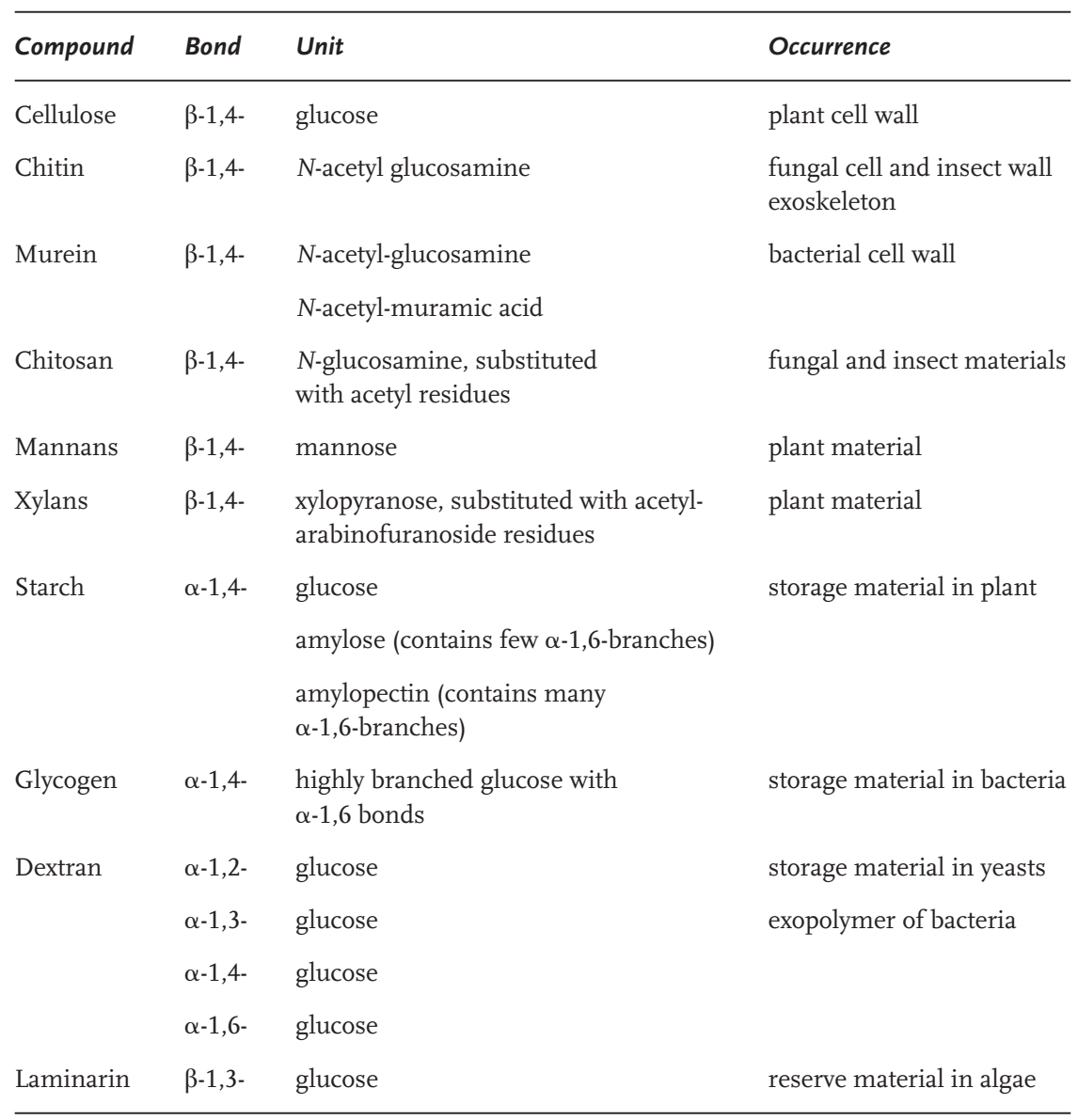




\section{2 .5}

\section{Biomass Degradation in the Presence of Inorganic Electron Acceptors and by an Anaerobic Food Chain}

In ecosystems in which molecular oxygen is available, plant and animal biomass is degraded to $\mathrm{CO}_{2}$ and $\mathrm{H}_{2} \mathrm{O}$, catalyzed by either single species of aerobic microorganisms or the whole population of the ecosystem, in competition for the substrates. A single organism may be able to hydrolyze the polymers and oxidize the monomers to $\mathrm{CO}_{2}$ and $\mathrm{H}_{2} \mathrm{O}$ with oxygen. In ecosystems where molecular oxygen is deficient such as swamps, wet soil, the rumen of animals, the digestive tract of humans, or in river and lake sediments - oxidation of dead biomass proceeds anoxically by reduction of electron acceptors such as nitrate and nitrite or anaerobically by reduction of sulfate, $\mathrm{Fe}^{3+}, \mathrm{Mn}^{4+}$, or $\mathrm{CO}_{2}$. The oxidation of the carbon source is either complete or incomplete with acetate excretion. In the absence of inorganic electron acceptors, oxidized metabolites such as pyruvate or acetate are reduced to lactate or ethanol or biotransformed to, e.g., $n$-butyrate or $n$-butanol. In permanently anaerobic ecosystems with seasonal overfeeding, periodic accumulation of such metabolites can occur, e.g., in autumn after the non-evergreen plants drop their leaves or decay completely. The biopolymers of the leaves or the plants themselves decompose by extracellular enzymatic hydrolysis. The monomers are fermented, and the fermentation products may be degraded further to biogas by acetogenic and methanogenic bacteria. Whereas single cultures of aerobes can catalyze the whole mineralization process to finally form $\mathrm{CO}_{2}$ and $\mathrm{H}_{2} \mathrm{O}$, single cultures of strictly anaerobic bacteria are not capable of degrading biopolymers to $\mathrm{CH}_{4}$ and $\mathrm{CO}_{2}$. Under anaerobic conditions biopolymers must be degraded by a food chain via depolymerization (hydrolysis), fermentation (acidogenesis), oxidation of fatty acids (acetogenesis), and biogas formation (methanogenesis) as the last step (McInerney, 1988). In an initial exoenzyme-catalyzed reaction the biopolymers are hydrolyzed to soluble mono-, di-, or oligomers. These are taken up by the bacteria and fermented to $\mathrm{CO}_{2}, \mathrm{H}_{2}$, formate, acetate, propionate, butyrate, lactate, etc. If fatty acid isomers are produced, they are mainly derived from degradation of amino acids after proteolysis. Fatty acids are further oxidized by acetogenic bacteria, before the cleavage products $\mathrm{CO}_{2}, \mathrm{H}_{2}$, and acetate can be taken up by methanogens and be converted to methane and $\mathrm{CO}_{2}$. Lactate is oxidized to pyruvate, which is decarboxylated to yield acetate, $\mathrm{CO}_{2}$, and $\mathrm{H}_{2}$. If ethanol is present, it is oxidized to acetate and hydrogen, and the hydrogen is used for $\mathrm{CO}_{2}$ reduction.

Table 1.3 summarizes the reactions that can be catalyzed by methanogens and that can contribute to methane emission in various ecosystems. In sewage digesters about two thirds of the methane is derived from acetate cleavage and one third from $\mathrm{CO}_{2}$ reduction with $\mathrm{H}_{2}$. If hexoses are the substrates and glycolysis is the main degradation pathway, then the $2 \mathrm{~mol}$ of pyruvate can be decarboxylated by pyruvate: ferredoxin oxidoreductase to yield $2 \mathrm{~mol}$ acetate and $2 \mathrm{~mol} \mathrm{CO}_{2}$. The hydrogens of the $2 \mathrm{~mol} \mathrm{NADH}_{2}$ from glycolysis and the $2 \mathrm{~mol} \mathrm{FdH}_{2}$ from pyruvate decarboxylation are then released as molecular hydrogen at low $\mathrm{H}_{2}$ partial pressure (Eq. 3). Two 
Table 1.3 Reactions catalyzed by methanogens and standard changes in free energy.

\begin{tabular}{|c|c|c|c|}
\hline \multicolumn{3}{|l|}{ Reaction } & \multirow{2}{*}{$\begin{array}{l}\Delta \mathrm{G}^{\circ \prime} \\
\text { (kJ per mol of methane) }\end{array}$} \\
\hline \multicolumn{2}{|l|}{ Substrates (mol) } & Products (mol) & \\
\hline Acetate & $\rightarrow$ & $\mathrm{CH}_{4}+\mathrm{CO}_{2}$ & -31.0 \\
\hline $4 \mathrm{H}_{2}+\mathrm{CO}_{2}$ & $\rightarrow$ & $\mathrm{CH}_{4}+2 \mathrm{H}_{2} \mathrm{O}$ & -135.6 \\
\hline $4 \mathrm{HCOOH}$ & $\rightarrow$ & $\mathrm{CH}_{4}+3 \mathrm{CO}_{2}+2 \mathrm{H}_{2} \mathrm{O}$ & -130.1 \\
\hline $4 \mathrm{CO}+2 \mathrm{H}_{2} \mathrm{O}$ & $\rightarrow$ & $\mathrm{CH}_{4}+3 \mathrm{CO}_{2}$ & -211.0 \\
\hline 4 Methanol & $\rightarrow$ & $3 \mathrm{CH}_{4}+\mathrm{CO}_{2}+2 \mathrm{H}_{2} \mathrm{O}$ & -104.9 \\
\hline Methanol $+\mathrm{H}_{2}$ & $\rightarrow$ & $\mathrm{CH}_{4}+\mathrm{H}_{2} \mathrm{O}$ & -112.5 \\
\hline 2 Ethanol $^{\mathrm{a}}+\mathrm{CO}_{2}$ & $\rightarrow$ & $\mathrm{CH}_{4}+2$ acetate & -116.3 \\
\hline 4 2-Propanol ${ }^{\mathrm{b}}+\mathrm{CO}_{2}$ & $\rightarrow$ & $\mathrm{CH}_{4}+4$ acetone $+2 \mathrm{H}_{2} \mathrm{O}$ & -36.5 \\
\hline 4 Methylamine $+2 \mathrm{H}_{2} \mathrm{O}$ & $\rightarrow$ & $3 \mathrm{CH}_{4}+\mathrm{CO}_{2}+4 \mathrm{NH}_{3}$ & -75.0 \\
\hline 2 Dimethylamine $+2 \mathrm{H}_{2} \mathrm{O}$ & $\rightarrow$ & $3 \mathrm{CH}_{4}+\mathrm{CO}_{2}+2 \mathrm{NH}_{3}$ & -73.2 \\
\hline 4 Trimethylamine $+6 \mathrm{H}_{2} \mathrm{O}$ & $\rightarrow$ & $9 \mathrm{CH}_{4}+3 \mathrm{CO}_{2}+4 \mathrm{NH}_{3}$ & -74.3 \\
\hline 2 Dimethylsulfide $+2 \mathrm{H}_{2} \mathrm{O}$ & $\rightarrow$ & $3 \mathrm{CH}_{4}+\mathrm{CO}_{2}+2 \mathrm{H}_{2} \mathrm{~S}$ & -73.8 \\
\hline \multicolumn{4}{|c|}{$\begin{array}{l}\text { Other primary alcohols that are used as hydrogen donors for } \mathrm{CO}_{2} \text { reduction are 1-propanol and } \\
\text { 1-butanol (in a few species). }\end{array}$} \\
\hline \multicolumn{4}{|c|}{$\begin{array}{l}\text { bther secondary alcohols used as hydrogen donors for } \mathrm{CO}_{2} \text { reduction are 2-butanol, 1,3-butanediol, } \\
\text { cyclopentanol, and cyclohexanol (in a few species). }\end{array}$} \\
\hline
\end{tabular}

moles of $\mathrm{CH}_{4}$ are then formed from acetate and $1 \mathrm{~mol}$ of $\mathrm{CH}_{4}$ by $\mathrm{CO}_{2}$ reduction (reactions 1 and 2 of Table 1.3).

$1 \mathrm{~mol}$ glucose $\rightarrow 2 \mathrm{~mol}$ acetate $+2 \mathrm{~mol} \mathrm{CO}_{2}+4 \mathrm{~mol} \mathrm{H}_{2}$ (at low $\left.p \mathrm{H}_{2}\right)$

In complex ecosystems formate is formed if high concentrations of hydrogen accumulate. Syntrophic interactions are usually associated with interspecies hydrogen transfer, but evidence for interspecies formate transfer was also reported (Thiele et al., 1988). The feasibility of the electron carrier depends on its solubility, which is much less for hydrogen than for formate, and on its diffusion coefficient in water, which favors hydrogen 30 times over formate. The efficiency of the appropriate electron transfer depends mainly on the distance between the producing and consuming bacteria. It can be expected, that formate transfer is favored when the distance between communicating bacteria is high and hydrogen transfer when the distance is small (de Bok et al., 2004). Interspecies formate transfer is thought to play a major role in degradation of syntrophic butyrate (Boone et al., 1989) and propionate (Stams, 1994; Schink, 1997). However, at an increased $\mathrm{H}_{2}$ partial pressure formate is also produced by methanogens, either in pure cultures or in a sewage sludge population (Bleicher and Winter, 1994), and this may also contribute to increasing formate concentrations. Other substrates for methanogenic bacteria (Table 1.3), such as methanol (derived, e.g., from methoxy groups of lignin monomers) or methyl- 
amines and dimethylsulfide (e.g., from methylsulfonopropionate in algae; Fritsche, 1998) are relevant only in ecosystems where these substances are produced during microbial decay. A few methanogens can also use reduced products such as primary, secondary, and cyclic alcohols as a source of electrons for $\mathrm{CO}_{2}$ reduction (Widdel, 1986; Zellner and Winter, 1987a; Bleicher et al., 1989; Zellner et al., 1989).

\section{2 .6}

\section{Roles of Molecular Hydrogen and Acetate During Anaerobic Biopolymer Degradation}

Molecular hydrogen is produced during different stages of anaerobic degradation. In the fermentative stage, organisms such as Clostridium sp. and Eubacterium sp. produce fatty acids, $\mathrm{CO}_{2}$, and hydrogen from carbohydrates. In the acetogenic stage, acetogens such as Syntrophobacter wolinii and Syntrophomonas wolfei produce acetate, $\mathrm{CO}_{2}$, and hydrogen or acetate and hydrogen by anaerobic oxidation of propionate and $n$-butyrate (McInerney, 1988). Fermentative bacteria release molecular hydrogen even at a high $\mathrm{H}_{2}$ partial pressure and simultaneously excrete reduced products (e.g., clostridia, Ruminococcus, Eubacterium sp.). However, the release of molecular hydrogen during acetogenesis of fatty acids or of other reduced metabolites may occur only when hydrogen does not accumulate, for thermodynamic reasons. Molecular hydrogen is consumed by methanogens (Table 1.4, reaction 1) or, alternatively, by sulfate reducers (Table 1.4, reaction 2 ) via interspecies hydrogen transfer. In the rumen and in sewage sludge digesters, the hydrogen concentration can be decreased by acetate formation from $\mathrm{CO}_{2}$ and $\mathrm{H}_{2}$ (Table 1.4, reaction 3) by bacteria such as Acetobacterium woodii and Clostridium thermoaceticum. Some additional reactions consuming hydrogen to decrease its concentration are also listed in Table 1.4 (reactions 4-6).

To maintain a low $\mathrm{H}_{2}$ partial pressure, a syntrophism of acetogenic, hydrogenproducing and methanogenic, hydrogen-utilizing bacteria is essential (Ianotti et al., 1973). Complete anaerobic degradation of fatty acids with hydrogen formation by obligate proton-reducing acetogenic bacteria is possible only at $\mathrm{H}_{2}$ partial pressures $<10^{-4} \mathrm{~atm}$ ( $n$-butyrate) or $10^{-5} \mathrm{~atm}$ (propionate), which cannot be maintained by

Table 1.4 Hydrogen-consuming reactions in anaerobic ecosystems (Schink, 1997).

\begin{tabular}{|c|c|c|c|c|}
\hline \multicolumn{3}{|c|}{ Substrates (mol) } & \multirow{2}{*}{$\begin{array}{l}\text { Products (mol) } \\
\mathrm{CH}_{4}+2 \mathrm{H}_{2} \mathrm{O}\end{array}$} & \multirow{2}{*}{$\begin{array}{l}\Delta G^{\circ /} \\
\text { (kJ per mol) } \\
-131.0\end{array}$} \\
\hline (1) & $4 \mathrm{H}_{2}+\mathrm{CO}_{2}$ & $\rightarrow$ & & \\
\hline (2) & $4 \mathrm{H}_{2}+\mathrm{SO}_{4}^{2-}$ & $\rightarrow$ & $\mathrm{S}^{2-}+4 \mathrm{H}_{2} \mathrm{O}$ & -151.0 \\
\hline (3) & $4 \mathrm{H}_{2}+2 \mathrm{CO}_{2}$ & $\rightarrow$ & $\mathrm{CH}_{3} \mathrm{COO}^{-}+\mathrm{H}^{+}+2 \mathrm{H}_{2} \mathrm{O}$ & -0.9 \\
\hline (4) & $\mathrm{H}_{2}+\mathrm{S}^{\mathrm{O}}$ & $\rightarrow$ & $\mathrm{H}_{2} \mathrm{~S}$ & -0.9 \\
\hline (5) & $\mathrm{H}_{2} \mathrm{C}\left(\mathrm{NH}_{3}^{+}\right) \mathrm{COO}^{-}+\mathrm{H}_{2}$ & $\rightarrow$ & $\mathrm{CH}_{3} \mathrm{COO}^{-}+\mathrm{NH}_{4}^{+}$ & 0.0 \\
\hline (6) & $\mathrm{COOH}-\mathrm{CH}-\mathrm{CH}-\mathrm{COOH}+\mathrm{H}_{2}$ & $\rightarrow$ & $\mathrm{COOH}-\mathrm{CH}_{2}-\mathrm{CH}_{2}-\mathrm{COOH}$ & 0.0 \\
\hline
\end{tabular}


methanogens or sulfate reducers. However, by reversed electron transport electrons can be shifted to a lower redox potential suitable for proton reduction (Schink, 1997). If hydrogen accumulates beyond this threshold concentration, the anaerobic oxidation of fatty acids becomes endergonic and does not proceed (for details, see Chapter 8 , this volume). Whereas hydrogen prevents $\beta$ oxidation of fatty acids by acetogens even at very low $\mathrm{H}_{2}$ partial pressure, much higher concentrations of acetate (in the millimolar range) are required for the same effect.

The fermentative metabolism of acidogenic bacteria is exergonic even at $\mathrm{H}_{2}$ partial pressures $>10^{-4} \mathrm{~atm}$. Whereas acetogenic bacteria apparently depend mainly on ATP generation by chemiosmotic phosphorylation, fermentative bacteria produce most of their ATP by substrate chain phosphorylation. This may be why fermentative bacteria do not depend on a syntrophic interaction with electron-consuming bacteria, such as methanogens or sulfate reducers.

In addition to the possibility of anaerobic oxidation of organic compounds via synthrophic interactions between acetogenic bacteria and acetoclastic + hydrogenotrophic methanogens (see also Section 1.2.5), other synthrophic associations between acetate-oxidizing bacteria and $\mathrm{H}_{2} / \mathrm{CO}_{2}$-utilizing methanogens under thermophilic (Lee and Zinder 1988) and mesophilic (Schnuerer et al. 1996) growth conditions have been observed. Thermodynamic analysis of mesophilic synthrophic acetate oxidation revealed a hydrogen partial pressure of $<0.1-2.6 \mathrm{~Pa}$, which is in the range found in methanogenic ecosystems (Dolfing, 2001). In thermophilic methanogenic reactors, acetate is degraded either by synthrophic acetate oxidizers (dominant process at low acetate concentrations) and acetate-degrading methanogens (acetate concentration above the threshold concentration) or by acetate-utilizing methanogens of the genera Methanosaeta or Methanosarcina (Ahring, 2003). Synthrophic acetate oxidation and methane formation from the cleavage products may explain the lack of acetoclastic methanogens (Methanosarcina sp. or Methanosaeta sp.) in anaerobic reactors.

\subsection{7}

\section{Anaerobic Conversion of Biopolymers to Methane and $\mathrm{CO}_{2}$}

The principle of the anaerobic metabolism of biopolymers was outlined by the pioneering work of Wolin (1976) and Bryant (1979). There is an essential requirement for syntrophic interaction between different metabolic groups for complete anaerobic degradation (Wolin, 1976, 1982). The most sensitive switch of the carbon flow of substrates to biogas is the $\mathrm{H}_{2}$ partial pressure. The substrate supply for biomethanation processes must be limited so that the most slowly growing group in the food chain, the obligate proton-reducing acetogens, can still excrete hydrogen at a maximum rate, but at the same time hydrogen accumulation $>10^{-5} \mathrm{~atm}$ is prevented by active methanogenesis or sulfate reduction (Bryant, 1979). Whereas hydrogen seemed to be the most sensitive regulator of anaerobic degradation, formate (Bleicher and Winter, 1994), acetate, or other fatty acids accumulated to much higher concentrations (McInerney, 1988) but did not repress anaerobic degradation. If hydro- 
gen accumulated due to an oversupply or to inhibition of methanogens, anaerobic biodegradation was disturbed successively in different stages. Initially, in the acetogenic stage $\beta$ oxidation of fatty acids and alcohols failed, leading to an accumulation of these acid metabolites. Later, the spectrum of metabolites of the fermentative flora changed toward more reduced products like ethanol, lactate, propionate, and $n$ butyrate, leading to an even higher concentration of volatile fatty acids and a further decrease in $\mathrm{pH}$. At $\mathrm{pH}$ values below 6.5, methanogenic reactions were almost completely prevented. At this stage acidification with a rich spectrum of reduced products still proceeded.

\subsubsection{Anaerobic Degradation of Carbohydrates in Wastewater}

Carbohydrates are homo- or heteropolymers of hexoses, pentoses, or sugar derivatives, which occur in soluble form or as particles, forming grains or fibers of various sizes. In some plants, starch forms grains up to $1 \mathrm{~mm}$ in diameter, which is 1000 times the diameter of bacteria. Starch metabolism by bacteria requires hydrolytic cleavage by amylases to form soluble monomers or dimers, since only soluble substrates can be taken up and metabolized.

The anaerobic degradation of biopolymers in general and of cellulose in particular can be divided into hydrolytic, fermentative, acetogenic, and methanogenic phases (Fig. 1.3). Hydrolysis and fermentation of the hydrolysis products can be catalyzed by the same trophic group of microorganisms. The distinction of the two phases is of more theoretical than practical relevance. Concerning reaction rates in a methane fermenter that is fed with a particulate substrate, the rate-limiting step is hydrolysis rather than the subsequent fermentation of the monomers, if acetogenesis and methanogenesis proceed faster. The hydrolysis rates of polymers can be very different. Hemicellulose and pectin are hydrolyzed ten times faster than lignin-encrusted cellulose (Buchholz et al., 1986, 1988). In the acidification reactor of a two-stage anaerobic process, hydrolysis of polymers to monomers is normally slower than fermentation of monomers to fatty acids and other fermentation products. For this reason, no sugar monomers can be detected during steady-state operation. In the methane reactor, $\beta$ oxidation of fatty acids, especially of propionate or $n$-butyrate, is the ratelimiting step (Buchholz et al., 1986). Fatty acid degradation is the slowest reaction overall in a two-stage methane reactor fed with carbohydrate-containing wastewater from sugar production. Thus, the methane reactor has to be larger than the acidification reactor to permit longer hydraulic retention times.

The rate of cellulose degradation depends strongly on the state of the cellulose in the wastewater. If cellulose is lignin-encrusted, lignin prevents access of cellulases to the cellulose fibers. If cellulose is mainly in a crystalline form, cellulases can easily attach to it, and then hydrolysis can be a relatively fast process. At increasing loading in an anaerobic reactor fed with crystalline cellulose, acetogenesis became the rate-limiting process, leading to propionate and butyrate formation (Winter and Cooney, 1980). In decaying plant material, cellulose is very often lignin-encrusted. Due to the highly restricted access to these complexes by cellulases, hydrolysis of cellulose is the rate-limiting step in its degradation to methane and $\mathrm{CO}_{2}$. 


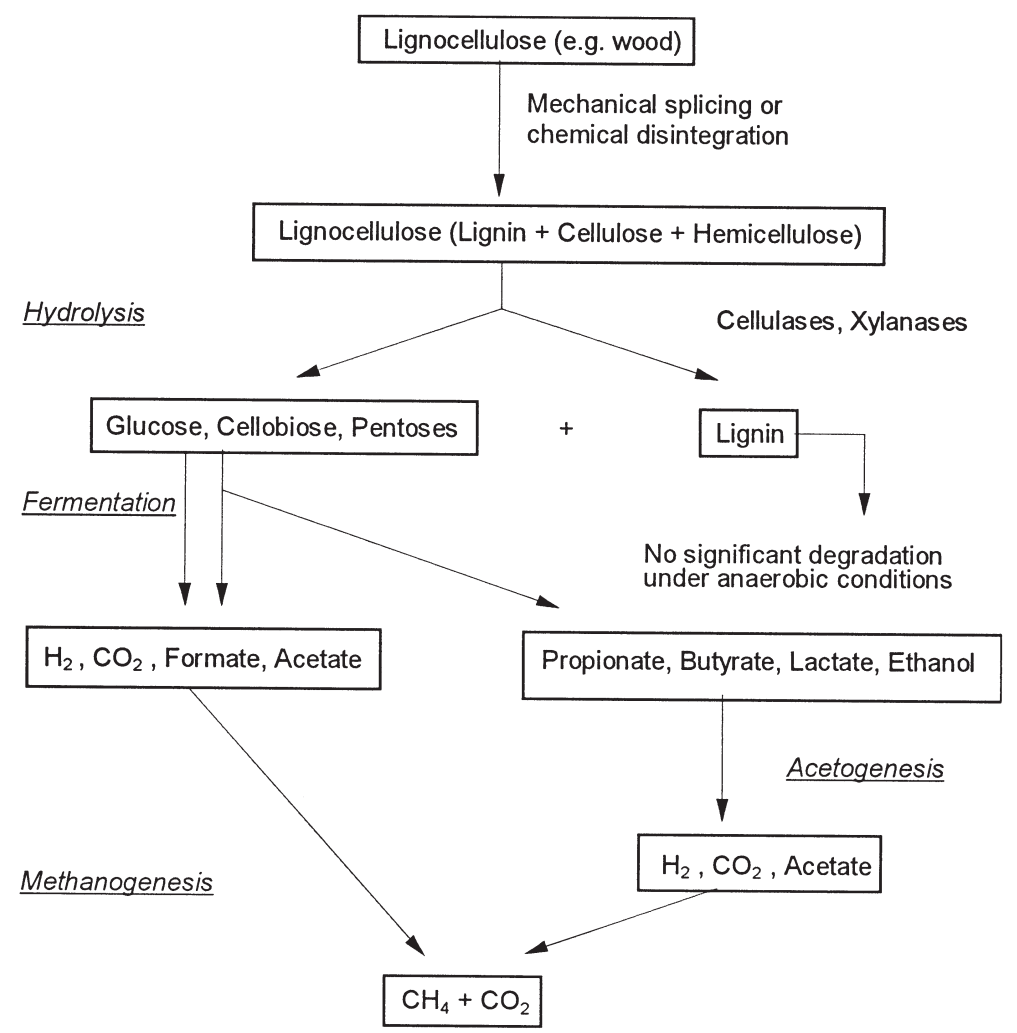

Fig. 1.3 Anaerobic degradation of lignocellulose and cellulose to methane and $\mathrm{CO}_{2}$ (according to ATV, 1994).

Whether microorganisms are capable of degrading lignin under anaerobic conditions is still under discussion. In a natural environment without time limitation, lignin was reported to be degraded anaerobically (Colberg and Young, 1985; Colberg, 1988). However, since these results were based on long-term experiments performed in situ and anaerobiosis was not controlled, it remains doubtful, whether the small amount of lignin that disappeared was really degraded under strictly anaerobic conditions. The occurrence of coal and fossil oil suggests that lignin compounds are highly resistant to microbial attack.

During anaerobic degradation of starch, hydrolysis by amylases proceeds with high velocity if good contact between starch grains and amylases is maintained. Whereas in an anaerobic reactor at low loading, starch degradation can proceed in the absence of acetogenic bacteria, as indicated in Figure 1.4 (route a), at high loading, volatile fatty acids are formed and acetogens are essential for total degradation (Fig. 1.4, route b). Figure 1.4 illustrates how the rate-limiting acetogenic reactions may be avoided by adjusting the conditions so that hydrolysis and fermentation occur no faster than methanogenesis. The rationale behind this is that many fermen- 
tative bacteria produce only acetate, formate, $\mathrm{CO}_{2}$, and hydrogen when $\mathrm{H}_{2}$-scavenging methanogens or sulfate reducers are able to maintain a sufficiently low $\mathrm{H}_{2}$ partial pressure, but a wide spectrum of fermentation products, typical for the metabolism of the respective bacterial species in pure culture, is produced at higher $\mathrm{H}_{2}$ partial pressure (Winter, 1983, 1984). Methanogenesis in continuous syntrophic methanogenic cultures can be disturbed by spike concentrations of sugars or - at low concentrations of sugars - by the presence of inhibitory substances like $\mathrm{NH}_{3}$, $\mathrm{H}_{2} \mathrm{~S}$, antibiotics (Hammes et al., 1979; Hilpert et al., 1981), or xenobiotics. In consequence, the $\mathrm{H}_{2}$ partial pressure increases and volatile fatty acids are generated (Winter, 1984; Winter et al., 1989; Wildenauer and Winter, 1985; Zellner and Winter, $1987 b)$. Once propionate or $n$-butyrate are produced, anaerobic degradation requires acetogens for $\beta$ oxidation (Fig. 1.4, route b).

\subsubsection{Anaerobic Degradation of Protein}

Proteins are biological macromolecules, either soluble or solid (e.g., feathers, hair, nails). Outside the cell at an acid $\mathrm{pH}$ or in the presence of enzymes, soluble proteins precipitate, e.g., precipitation of casein by addition of rennet enzyme. The reaction sequences necessary for protein degradation in a methanogenic ecosystem are outlined in Figure 1.5. Hydrolysis of precipitated or soluble protein is catalyzed by sev-

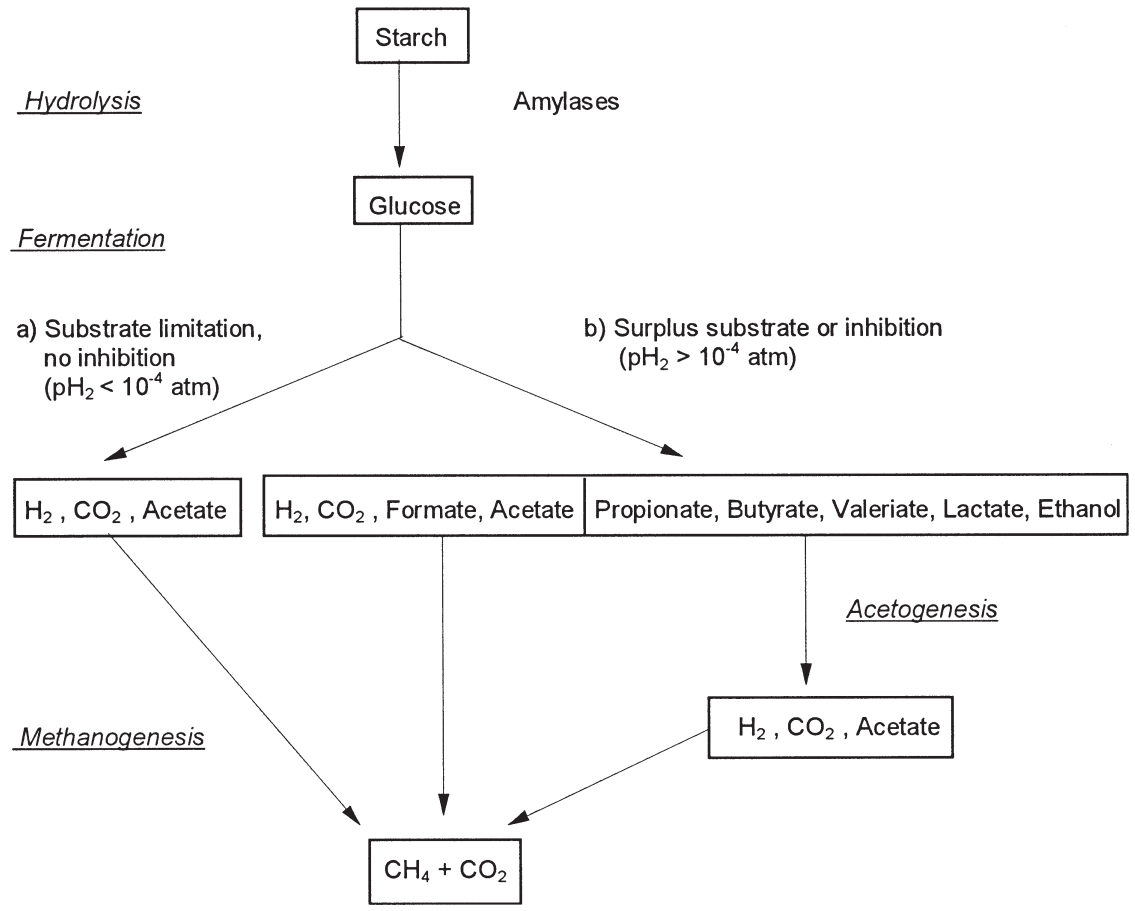

Fig. 1.4 Anaerobic degradation of starch under low- and high-loading conditions. 


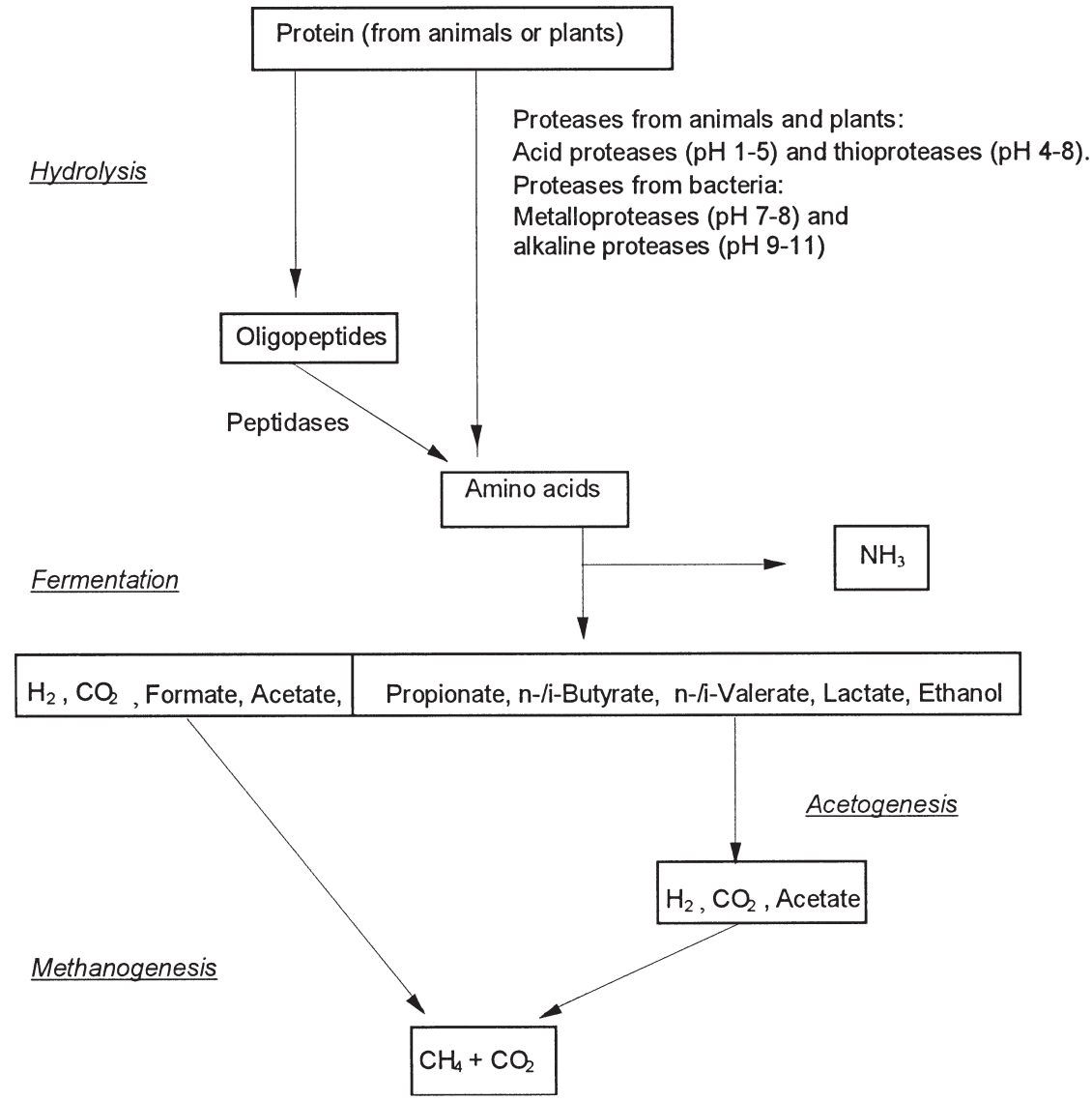

Fig. 1.5 Anaerobic degradation of proteins.

eral types of proteases that cleave membrane-permeable amino acids, dipeptides, or oligopeptides. In contrast to the hydrolysis of carbohydrates, which proceeds favorably at a slightly acid $\mathrm{pH}$, optimal hydrolysis of proteins requires a neutral or weakly alkaline $\mathrm{pH}$ (McInerney, 1988). In contrast to the fermentation of carbohydrates, which lowers the $\mathrm{pH}$ due to volatile fatty acid formation, fermentation of amino acids in wastewater reactors does not lead to a significant $\mathrm{pH}$ change, due to acid and ammonia formation. Acidification of protein-containing wastewater proceeds optimally at $\mathrm{pH}$ values of 7 or higher (Winterberg and Sahm, 1992), and ammonium ions together with the $\mathrm{CO}_{2}$-bicarbonate-carbonate buffer system stabilize the $\mathrm{pH}$. Acetogenesis of fatty acids from deamination of amino acids requires a low $\mathrm{H}_{2}$ partial pressure for the same reasons as for carbohydrate degradation. This can be maintained by a syntrophic interaction of fermentative, protein-degrading bacteria and acetogenic and methanogenic or sulfate-reducing bacteria. Except for syntrophic interaction of amino acid-degrading bacteria with methanogens for maintenance 
of a low $\mathrm{H}_{2}$ partial pressure, clostridia and presumably also some other sludge bacteria may couple oxidative and reductive amino acid conversion via the Stickland reaction. One amino acid, e.g., alanine (Eq. 4) is oxidatively decarboxylated and the hydrogen or reducing equivalents produced during this reaction are used to reductively convert another amino acid, e.g., glycine, to acetate and ammonia (Eq. 5).

$$
\begin{aligned}
& \mathrm{CH}_{3}-\mathrm{CHNH}_{2}-\mathrm{COOH}+2 \mathrm{H}_{2} \mathrm{O} \rightarrow \mathrm{CH}_{3}-\mathrm{COOH}+\mathrm{CO}_{2}+\mathrm{NH}_{3}+2 \mathrm{H}_{2} \\
& \Delta \mathrm{G}^{\circ \prime}=+7.5 \mathrm{~kJ} \mathrm{~mol}{ }^{-1} \\
& 2 \mathrm{CH}_{2} \mathrm{NH}_{2}-\mathrm{COOH}+2 \mathrm{H}_{2} \rightarrow 2 \mathrm{CH}_{3} \mathrm{COOH}+2 \mathrm{NH}_{3} \\
& \Delta G^{\circ \prime}=-38.9 \mathrm{~kJ} \mathrm{~mol}^{-1}
\end{aligned}
$$

For complete degradation of amino acids in an anaerobic system therefore, a syntrophism of amino acid-fermenting anaerobic bacteria with methanogens or sulfate reducers is required (Wildenauer and Winter, 1986; Winter et al., 1987; Örlygsson et al., 1995). If long-chain amino acids are deaminated (Eqs. 6-9), fatty acids such as propionate, $i$-butyrate, or $i$-valerate are formed directly. The fatty acids require acetogenic bacteria for their degradation.

$$
\begin{aligned}
& \text { valine }+2 \mathrm{H}_{2} \mathrm{O} \rightarrow i \text {-butyrate }+\mathrm{CO}_{2}+\mathrm{NH}_{3}+2 \mathrm{H}_{2} \\
& \text { leucine }+2 \mathrm{H}_{2} \mathrm{O} \rightarrow \text {-valerate }+\mathrm{CO}_{2}+\mathrm{NH}_{3}+2 \mathrm{H}_{2} \\
& \text { i-leucine }+2 \mathrm{H}_{2} \mathrm{O} \rightarrow \text {-methylbutyrate }+\mathrm{CO}_{2}+\mathrm{NH}_{3}+2 \mathrm{H}_{2} \\
& \text { glutamate }+2 \mathrm{H}_{2} \mathrm{O} \rightarrow \text { propionate }+2 \mathrm{CO}_{2}+\mathrm{NH}_{3}+2 \mathrm{H}_{2}
\end{aligned}
$$

In contrast to carbohydrate degradation, where the necessity for propionate- and butyrate-degrading acetogenic bacteria can be circumvented by substrate limitation (Fig. 1.4a), during protein degradation these fatty acids are a product of deamination, and their formation cannot be avoided by maintaining a low $\mathrm{H}_{2}$ partial pressure. In the methanogenic phase there is no difference in methanogenic activity whether carbohydrates or proteins are fermented, except that the methanogens in a reactor fed with protein need to be more tolerant to ammonia and higher $\mathrm{pH}$.

\subsubsection{Anaerobic Degradation of Neutral Fats and Lipids}

Fats and lipids are another group of biopolymers that contribute significantly to the COD in sewage sludge, cattle and swine manures, and wastewater from the food industry, e.g., slaughterhouses or potato chip factories (Winter et al., 1992; Broughton et al., 1998). To provide a maximum surface for hydrolytic cleavage by lipases or phospholipases, solid fats, lipids, or oils must be emulsified. Glycerol and saturated and unsaturated fatty acids (palmitic acid, linolic acid, linolenic acid, stearic acid, etc.) are formed from neutral fats. Lipolysis of phospholipids generates fatty acids, glycerol, alcohols (serine, ethanolamine, choline, inositol), and phosphate. Lipolysis of sphingolipids generates fatty acids and amino alcohols (e.g., sphingosine), and lipolysis of glycolipids generates fatty acids, amino alcohols, and hexoses (glucose, galactose). A scheme for anaerobic degradation of fats is shown in Figure 1.6. Sugar moieties and glycerol can be degraded to methane and $\mathrm{CO}_{2}$ by interaction between 
fermentative and methanogenic bacteria in low-loaded systems or by cooperation between fermentative, acetogenic, and methanogenic bacteria in high-loaded systems. The long-chain fatty acids are degraded by acetogenic bacteria by $\beta$ oxidation to acetate and molecular hydrogen. If acetate and molecular hydrogen accumulate, the anaerobic digestion process is inhibited (Hanaki et al., 1981). Odd-numbered fatty acids are degraded to acetate, propionate, and hydrogen, and even-numbered fatty acids to acetate and hydrogen (Bryant, 1979). Only at a very low $\mathrm{H}_{2}$ partial pressure, which can be maintained by hydrogen-utilizing methanogens or sulfate reducers, is $\beta$ oxidation of at least $n$-butyrate or propionate exergonic. Methanol, ethanol, and ammonia are formed from choline (Fig. 1.6). After hydrolysis, fermentation, and acetogenesis of the fat components in the methanogenic phase acetate, $\mathrm{CO}_{2}$, and hydrogen are converted to biogas. All subsequent intracellular reactions can be influenced by syntrophic interaction via interspecies hydrogen transfer, except for the extracellular initial lipase reaction.

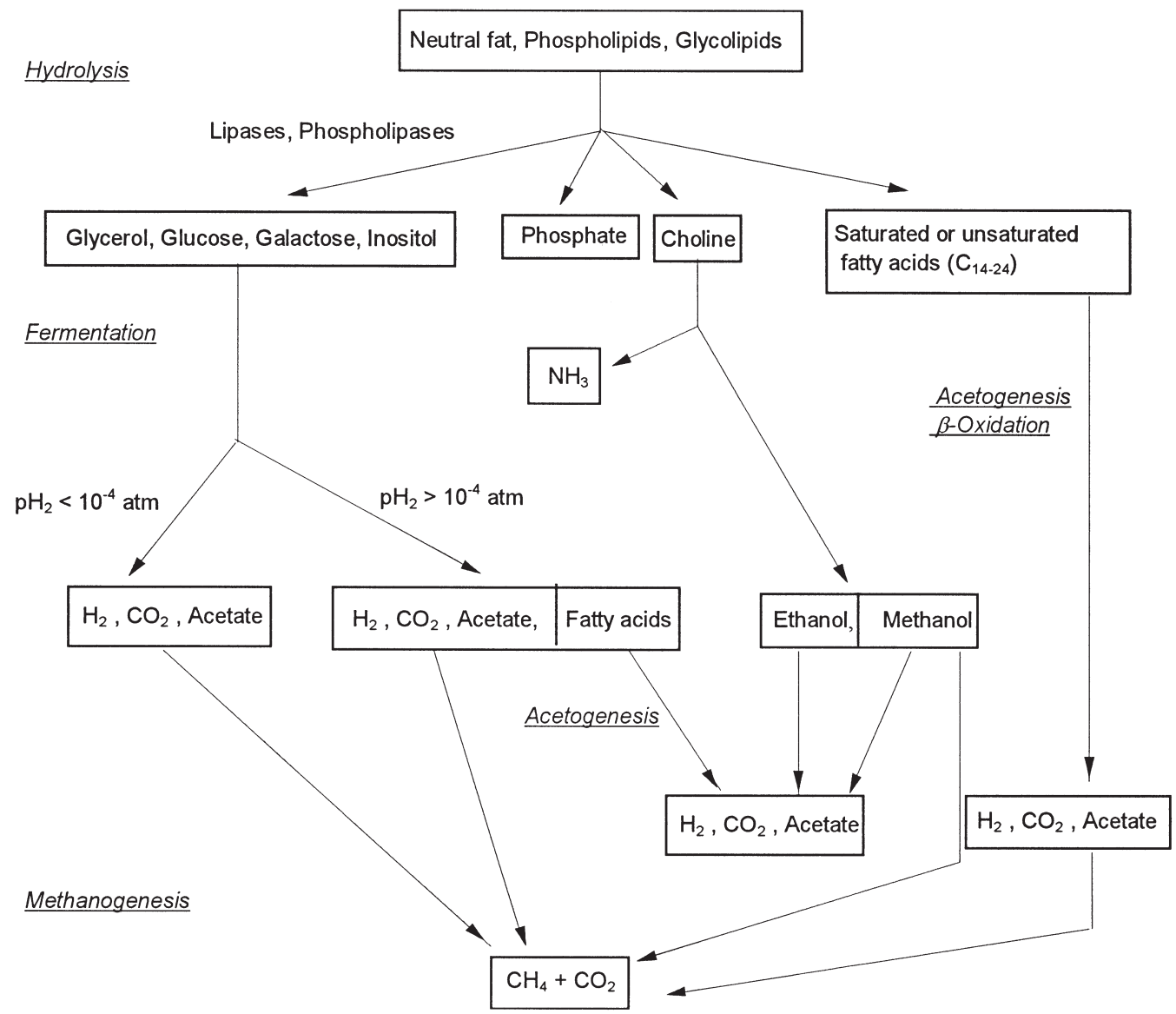

Fig. 1.6 Anaerobic degradation of fats. 
Carbohydrates, proteins, fats, and biogenic oils can also be degraded anaerobically under thermophilic conditions. The overall degradation scheme is the same, but the microorganism populations are different (e.g., Winter and Zellner, 1990). Thermophilic fat degradation is becoming more important in practice, since waste fat from fat separators and fat flotates of the food industry are often cofermented in agricultural biogas plants. Since, for hygienic reasons, the input material must be autoclaved, a thermophilic process should be used, keeping the fat in a melted, soluble form for more effective metabolism. Biogas plants with cofermentation of waste fat residues are considered waste treatment systems (Chapter 11, this volume) and must be designed to meet the hygienic demands relevant to treatment of the respective waste.

\section{2 .8}

\section{Competition of Sulfate Reducers with Methanogens in Methane Reactors}

Municipal wastewater or wastewater from sugar production, slaughterhouses, breweries, etc., normally contains less than $200 \mathrm{mg} \mathrm{L}^{-1}$ of sulfate. If sulfuric acid is used, e.g., to clean stainless steel containers and pipes in the dairy industry or to maintain an acid $\mathrm{pH}$ in bioreactors for bakers' yeast or citric acid production, or if ammonium sulfate is used to inhibit metabolic routes in bakers' yeast for the production of biochemicals, the wastewater contains large amounts of sulfate. Sulfite-containing wastewater is also generated by the starch and cellulose industry during bleaching of the raw products.

If these wastewaters are subjected to anaerobic treatment, the methanogenic bacteria must compete with sulfate reducers for the hydrogen equivalents from COD degradation (Omil et al., 1998). In anaerobic digesters sulfate reduction is the favored reaction, due to the higher affinity of sulfate reducers for reducing equivalents or hydrogen, leading to sulfide production at the expense of reduced biogas formation. Sulfide subsequently forms heavy metal precipitates and, if still present in larger amounts, remains in solution and may be toxic to acetogens and methanogens. Some hydrogen sulfide leaves the reactor with the biogas, which may contain up to a few percent of $\mathrm{H}_{2} \mathrm{~S}$. Then gas purification is necessary before the gas can be used as fuel for gas engines. Hydrogen sulfide in biogas causes not only odor problems but also corrosion of fermenters and pipes. Methanogenesis of dissolved and particulate organic material in sulfate-rich wastewater is possible, if acidogenesis and sulfate reduction (stripping of $\mathrm{H}_{2} \mathrm{~S}$ together with $\mathrm{CO}_{2}$ ) is separated from methanogenesis in a phased or a staged process (Lens et al., 2002). The higher affinity of sulfate reducers than methanogens for reducing equivalents can also be used for sulfate and heavy metal ion removal from wastewater in the first stage of a two-stage anaerobic process (Elferink et al., 1994).

In comparison to methanogens, which have a rather restricted substrate spectrum (Table 1.3), sulfate reducers are metabolically more versatile. Sulfate reducers can utilize polymers such as starch, monomers such as sugars, fatty acids, formate, aliphatic and aromatic compounds, as well as molecular hydrogen (Widdel, 1988) to generate reducing equivalents for sulfate reduction (Eq. 10): 


$$
8(\mathrm{H})+2 \mathrm{H}^{+}+\mathrm{SO}_{4}^{2-} \rightarrow \mathrm{H}_{2} \mathrm{~S}+4 \mathrm{H}_{2} \mathrm{O}
$$

Undissociated hydrogen sulfide is toxic to both methanogens and sulfate reducers. A 50\% inhibition of methanogenesis was observed at a total sulfide concentration of $270 \mathrm{mg} \mathrm{L}^{-1}$ (Oleszkiewicz et al., 1989), whereas $85 \mathrm{mg} \mathrm{L}^{-1}$ sulfide inhibited sulfate reducers (McCartney and Oleszkiewicz, 1991). For stable methanogenesis, no more than $150 \mathrm{mg} \mathrm{L}^{-1}$ sulfide should be accumulated (Speece et al., 1986). $\mathrm{H}_{2} \mathrm{~S}$ toxicity can be avoided by intensive flushing with biogas to strip the $\mathrm{H}_{2} \mathrm{~S}$ for adsorption onto $\mathrm{Fe}_{2}(\mathrm{OH})_{3}$. If large amounts of $\mathrm{H}_{2} \mathrm{~S}$ are formed during anaerobic treatment, essential heavy metal ions for methanogens (Fe, Ni, Mo, Co, etc.) may be precipitated as sulfides, which may lead to deficiencies in heavy metal bioavailability for the wastewater population.

The metabolites of the fermentative and acetogenic phase of anaerobic wastewater treatment systems, mainly acetate and $\mathrm{CO}_{2}+\mathrm{H}_{2}$, are substrates for methanogens and for sulfate reducers. If wastewater with a high sulfate concentration is treated in a methane reactor, the population may gradually shift from hydrogenotrophic methanogens toward hydrogenotrophic sulfate reducers, due to a more favorable $K_{\mathrm{s}}$ value for hydrogen of the sulfate reducers. For pure cultures of Desulfovibrio sp. the $K_{\mathrm{s}}$ value for hydrogen is $1 \mu \mathrm{M}$, but for hydrogenotrophic methanogens it is only $6 \mu \mathrm{M}$ (Kristjansson et al., 1982). For acetate, such a dramatic disadvantage of methanogens was not observed. The affinities of sulfate reducers and of methanogenic bacteria (valid at least for Methanosaeta sp.) for hydrogen are in the same range, 0.2-0.4 $\mu \mathrm{M}$ (Elferink et al., 1994).

\section{2 .9}

\section{Amount and Composition of Biogas During Fermentation of Carbohydrates, Proteins, and Fats}

From an economic point of view, the specific biogas amounts and the biogas quality from anaerobic treatment of wastewater and sludge are important process parameters. Therefore, a basis for prediction of amount and composition of biogas was elaborated as early as the 1930s (Buswell and Neave, 1930; Buswell and Sollo 1948; Buswell and Mueller, 1952). If the elemental composition of a wastewater is known, the theoretical amount and composition of the biogas can be predicted with the Buswell equation (Eq. 11). The actual biogas amount is lower and can be calculated by including a correction factor for the degree of degradability, the $\mathrm{pH}$ (which influences $\mathrm{CO}_{2}$ absorption), and a 5\%-10\% discount for biomass formation.

$$
\begin{aligned}
& \mathrm{C}_{c} \mathrm{H}_{h} \mathrm{O}_{o} \mathrm{~N}_{n} \mathrm{~S}_{s}+1 / 4(4 c-h-2 o+3 n+2 s) \mathrm{H}_{2} \mathrm{O} \rightarrow 1 / 8(4 c-h+2 o+3 n+2 s) \mathrm{CO}_{2} \\
& +1 / 8(4 c+h-2 o-3 n-2 s) \mathrm{CH}_{4}+n \mathrm{NH}_{3}+s \mathrm{H}_{2} \mathrm{~S}
\end{aligned}
$$

According to the Buswell equation (Eq. 11), for the anaerobic treatment of a wastewater with carbohydrates as pollutants, the gas composition should theoretically be $50 \%$ methane and $50 \% \mathrm{CO}_{2}$ (Eq. 12): 
$1 \mathrm{~mol} \mathrm{C}_{6} \mathrm{H}_{12} \mathrm{O}_{6} \rightarrow 3 \mathrm{~mol} \mathrm{CH}_{4}+3 \mathrm{~mol} \mathrm{CO}_{2}$

Since $\mathrm{CO}_{2}$ is increasingly soluble in water with decreasing temperature and increasing $\mathrm{pH}, \mathrm{CO}_{2}$ reacts to form bicarbonate/carbonate, and the biogas may contain more than $80 \%$ methane. The total amount of gas is then diminished by the amount of $\mathrm{CO}_{2}$ that is absorbed and solubilized in the liquid. From a fat- and protein-containing wastewater, theoretically more than $50 \%$ methane can be generated (Table 1.5 ).

\section{3}

\section{Nitrogen Removal During Wastewater Treatment}

Nitrogen-containing substances in wastewater are inorganic or organic. Together with phosphates, they represent the main source for eutrophication of surface water. For this reason they must be eliminated together with the organic carbon during wastewater treatment. Whereas phosphates form insoluble precipitates with many heavy metal ions and the precipitates can be separated by sedimentation or flotation, all nitrogen compounds, except for magnesium ammonium phosphate, are easily soluble in water and thus cannot be removed chemically by precipitation. For biological removal of amino nitrogen and of heterocyclic nitrogen compounds, their conversion to ammonia in an aerobic or anaerobic treatment process is the first step. Then ammonia must be nitrified, and the nitrate denitrified to yield nitrogen. Thus, depending on the kind of nitrogen compounds present in wastewater, nitrogen removal requires up to three processes in sequence: ammonification, nitrification, and denitrification.

The major portion of nitrogen compounds in municipal wastewater are reduced nitrogen compounds such as ammonia, urea, amines, amino acids, and proteins. Oxidized nitrogen compounds such as nitrate and nitrite normally are not present at all or not in relevant amounts. Nitrate and nitrite may, however, represent the main nitrogen load in wastewater of certain food or metal industry branches (Gensicke et al., 1998; Zayed and Winter, 1998).

Table 1.5 Amount of biogas, biogas composition, and energy content.

\begin{tabular}{lclll}
\hline Substrate & $\begin{array}{l}\text { Amount } \\
\left(\mathbf{c m}^{\mathbf{3}} \mathbf{g}^{-1}\right)\end{array}$ & $\begin{array}{l}\text { Composition } \\
\% \mathrm{CH}_{4}\end{array}$ & $\% \mathrm{CO}_{\mathbf{2}}$ & $\begin{array}{l}\text { Energy content } \\
\left(\mathbf{k W ~} \mathbf{h} \times \mathbf{m}^{-3}\right)^{d}\end{array}$ \\
\hline Carbohydrates $^{\mathrm{a}}$ & 746.7 & 50 & 50 & 4.95 \\
Fats $^{\mathrm{b}}$ & 1434 & 71 & 29 & 7.02 \\
Proteins $^{\mathrm{c}}$ & 636 & 60 & 40 & 5.93 \\
\hline
\end{tabular}

${ }^{\text {a }}$ Calculated for hexoses.

${ }^{\mathrm{b}}$ Calculated for triglycerides containing glycerol plus $3 \mathrm{~mol}$ palmitic acid.

${ }^{\mathrm{c}}$ Calculated for polyalanine and reaction of ammonia to $\left(\mathrm{NH}_{4}\right)_{2} \mathrm{CO}_{3}$.

${ }^{\mathrm{d}}$ at standard conditions 
The ammonia in raw municipal wastewater is mainly derived from urine and is formed in the sewer system by enzymatic cleavage of urea by ureases (Eq. 13):

$$
\mathrm{NH}_{2} \mathrm{CONH}_{2}+\mathrm{H}_{2} \mathrm{O} \rightarrow \mathrm{CO}_{2}+2 \mathrm{NH}_{3}
$$

The residence time of the wastewater in the sewer system normally is not long enough for a significant contribution of ammonia from other sources, e.g., proteolysis and deamination of amino acids.

\subsection{1}

\section{Ammonification}

The main organic nitrogen compounds in municipal wastewater are heterocyclic compounds (e.g., nucleic acids) and proteins. Proteolysis and degradation of amino acids leads to liberation of ammonia by the various mechanisms of ammonification (Rheinheimer et al., 1988), including hydrolytic, oxidative, reductive, and desaturative deamination (Eqs. 14-17, respectively)

$$
\begin{aligned}
& \mathrm{R}-\mathrm{NH}_{2}+\mathrm{H}_{2} \mathrm{O} \rightarrow \mathrm{R}-\mathrm{OH}+\mathrm{NH}_{3} \\
& \mathrm{R}-\mathrm{CHNH}_{2} \mathrm{COOH}+\mathrm{H}_{2} \mathrm{O} \rightarrow \mathrm{R}-\mathrm{CO}-\mathrm{COOH}+2(\mathrm{H})+\mathrm{NH}_{3} \\
& \mathrm{R}-\mathrm{CHNH}_{2}-\mathrm{COOH}+2(\mathrm{H}) \rightarrow \mathrm{R}-\mathrm{CH}_{2}-\mathrm{COOH}+\mathrm{NH}_{3} \\
& \mathrm{R}-\mathrm{CH}_{2}-\mathrm{CHNH}_{2}-\mathrm{COOH} \rightarrow \mathrm{R}-\mathrm{CH}=\mathrm{CH}-\mathrm{COOH}+\mathrm{NH}_{3}
\end{aligned}
$$

A significant amount of ammonia from urea cleavage or from ammonification of amino acids is assimilated in aerobic treatment processes for growth of bacteria (surplus sludge formation). It can be estimated that bacteria consist of roughly $50 \%$ protein and that the nitrogen content of protein is about $16 \%$. Thus, for synthesis of $1 \mathrm{~g}$ of bacterial biomass, about $0.08 \mathrm{~g}$ of ammonia- $\mathrm{N}$ is required. To eliminate ammonia that is not used for cell growth during wastewater treatment, it must first be nitrified and then denitrified to molecular nitrogen or anaerobically oxidized with nitrite.

\subsection{2}

\section{Nitrification of Ammonia}

\subsubsection{Autotrophic Nitrification}

Autotrophic nitrifiers are aerobic microorganisms oxidizing ammonia via nitrite (Eq. 18) to nitrate (Eq. 19). Organisms catalyzing nitrification (Eq. 18) belong to the genera Nitrosomonas, Nitrosococcus, Nitrosolobus, Nitrosospira, and Nitrosovibrio, organisms catalyzing nitration (Eq. 19) include, e.g., members of the genera Nitrobacter, Nitrococcus, and Nitrospira.

$$
\begin{aligned}
& \mathrm{NH}_{4}^{+}+1.5 \mathrm{O}_{2} \rightarrow \mathrm{NO}_{2}^{-}+2 \mathrm{H}^{+}+\mathrm{H}_{2} \mathrm{O} \\
& \mathrm{NO}_{2}^{-}+0.5 \mathrm{O}_{2} \rightarrow \mathrm{NO}_{3}^{-}
\end{aligned}
$$


Ammonia oxidation to nitrite or nitrite oxidation to nitrate are energy-yielding processes for the autotrophic growth of the nitrifying bacteria. $\mathrm{CO}_{2}$ is assimilated via the Calvin cycle. Since the positive redox potential of the oxidizable nitrogen compounds is not low enough to form $\mathrm{NADH}_{2}$ for $\mathrm{CO}_{2}$ reduction, $\mathrm{NADH}_{2}$ must be formed by an energy-consuming reverse electron transport. For this reason, the growth yield of nitrifying bacteria is low. Nitrosomonas sp., e.g., must oxidize $30 \mathrm{~g}$ $\mathrm{NH}_{3}$ to form $1 \mathrm{~g}$ of cell dry mass (Schlegel, 1992).

The oxidation of ammonia by nitrifiers is initiated by an energy-neutral monooxygenase reaction that yields hydroxylamine (Eq. 20):

$$
\mathrm{NH}_{3}+\mathrm{XH}_{2}+\mathrm{O}_{2} \rightarrow \mathrm{NH}_{2} \mathrm{OH}+X+\mathrm{H}_{2} \mathrm{O}
$$

Then hydroxylamine is further oxidized, presumably via nitroxyl (Eq. 21) to nitrite (Eq. 22), which is the energy-yielding reaction during nitrification. For microbial oxidation of $1 \mathrm{mg} \mathrm{NH}_{4}^{+}$-nitrogen to nitrite, $3.42 \mathrm{mg} \mathrm{O}_{2}$ is required, and for the oxidation of $1 \mathrm{mg} \mathrm{NO}_{2}^{-}$-nitrogen to nitrate (Eq. 19), $1.14 \mathrm{mg} \mathrm{O}_{2}$.

$$
\begin{aligned}
& \mathrm{NH}_{2} \mathrm{OH}+\mathrm{X} \rightarrow \mathrm{XH}_{2}+(\mathrm{NOH}) \\
& (\mathrm{NOH})+0.5 \mathrm{O}_{2} \rightarrow \mathrm{HNO}_{2}+\text { energy }
\end{aligned}
$$

Due to their slow growth autotrophic nitrifiers cannot successfully compete with heterotrophic bacteria for oxygen. In a highly loaded activated sludge system, the autotrophic nitrifiers are overgrown by the heterotrophic sludge flora, which consume the oxygen. Ammonia oxidation starts only if the $\mathrm{BOD}_{5}$ concentration in the wastewater is $<110 \mathrm{mg} \mathrm{L}^{-1}$ (Wild et al., 1971). During nitrification of ammonia the alkalinity of the wastewater increases slightly, due to $\mathrm{CO}_{2}$ consumption for autotrophic growth ( $\mathrm{pH}$ increase), but in a counter reaction it drastically decreases due to nitric acid formation from ammonia ( $\mathrm{pH}$ decrease from above neutral to acidic). If the buffer capacity of the wastewater is weak, the pH drops far below 7 and thus prevents further nitrification by autotrophic nitrifiers (Rheinheimer et al., 1988).

\subsubsection{Heterotrophic Nitrification}

Some bacteria of the genera Arthrobacter, Flavobacterium, and Thiosphaera are able to catalyze heterotrophic nitrification of nitrogen-containing organic substances (Eq. 23):

$$
\mathrm{R}-\mathrm{NH}_{2} \rightarrow \mathrm{R}-\mathrm{NHOH} \rightarrow \mathrm{R}-\mathrm{NO} \rightarrow \mathrm{NO}_{3}^{-}
$$

Heterotrophic nitrifiers oxidize reduced nitrogen compounds, such as hydroxylamine and aliphatic and aromatic nitrogen-containing compounds, but in contrast to autotrophic nitrification, no energy is gained by nitrate formation. For this reason an organic substrate must be respired to satisfy the energy metabolism (Schlegel, 1992) . 
Some heterotrophic nitrifiers can denitrify nitrate or nitrite under aerobic growth conditions. The nitrogen metabolism of Thiosphaera pantotropha and Paracoccus denitrificans are well documented examples (Stouthamer et al., 1997). These organisms express a membrane-bound nitrate reductase under anoxic growth conditions, which works only in the absence of molecular oxygen. Under aerobic growth conditions a periplasmic nitrate reductase is expressed, which catalyzes nitrate reduction at least to the state of nitrous oxide.

\subsection{3}

\section{Denitrification: Nitrate Removal from Wastewater}

Many aerobic bacteria seem to be able to switch their oxidative metabolism to nitrate respiration. Similar to oxygen respiration, the nitrate respiration of heterotrophic bacteria requires a complex carbon source as an electron source for denitrification (e.g., Eqs. 24 and 25). Denitrification (Eq. 26) starts with the reduction of nitrate to nitrite by membrane-bound nitrate reductase A (a). Then a membrane-bound nitrite reductase (b) catalyzes NO formation. Finally, NO reductase (c) and $\mathrm{N}_{2} \mathrm{O}$ reductase (d) form $\mathrm{N}_{2}$. The theoretical stoichiometry of denitrification with methanol or acetate as a carbon source is shown in Eqs. 27 and 28. For practical application a surplus of carbon source must be supplied, since the wastewater is not free of oxygen, and part of the carbon source is respired until anoxic conditions are achieved.

To evaluate the stoichiometry of nitrate to organic compounds for denitrification with a complex carbon source, the oxidation-reduction state of the carbon substrates and the oxygen concentration in the wastewater should be known. In wastewater treatment plants more than $2.85 \mathrm{~g}$ COD is required for reduction of $1 \mathrm{~g}$ $\mathrm{NO}_{3}^{-}-\mathrm{N}$ (Bernet et al., 1996).

$$
\begin{aligned}
& \mathrm{CH}_{3} \mathrm{OH}+\mathrm{H}_{2} \mathrm{O} \rightarrow \mathrm{CO}_{2}+6 \mathrm{H}^{+}+6 \mathrm{e}^{-} \\
& \mathrm{CH}_{3} \mathrm{COOH}+2 \mathrm{H}_{2} \mathrm{O} \rightarrow 2 \mathrm{CO}_{2}+8 \mathrm{H}^{+}+8 \mathrm{e}^{-} \\
& \mathrm{NO}_{3}^{-} \underset{a}{\stackrel{2 e^{-}}{\rightarrow}} \mathrm{NO}_{2}^{-} \underset{b}{\stackrel{e^{-}}{\rightarrow}} \mathrm{NO} \underset{c}{\stackrel{e^{-}}{\rightarrow}} 0.5 \mathrm{~N}_{2} \mathrm{O} \underset{d}{\stackrel{e^{-}}{\rightarrow}} 0.5 \mathrm{~N}_{2} \\
& 5 \mathrm{CH}_{3} \mathrm{OH}+6 \mathrm{HNO}_{3} \rightarrow 5 \mathrm{CO}_{2}+3 \mathrm{~N}_{2}+13 \mathrm{H}_{2} \mathrm{O} \\
& 5 \mathrm{CH}_{3}-\mathrm{COOH}+8 \mathrm{HNO}_{3} \rightarrow 10 \mathrm{CO}_{2}+4 \mathrm{~N}_{2}+14 \mathrm{H}_{2} \mathrm{O}
\end{aligned}
$$

Instead of nitrate, many denitrifying bacteria can use $\mathrm{NO}_{2}^{-}, \mathrm{NO}$, or $\mathrm{N}_{2} \mathrm{O}$ as terminal electron acceptors. Alternatively, they may release these intermediates during denitrification of nitrate under unfavorable conditions, as was observed in soil (Conrad, 1996). If, e.g., surplus nitrate is supplied and hydrogen donors are not sufficiently available, $\mathrm{NO}$ and $\mathrm{N}_{2} \mathrm{O}$ can be formed (Schön et al., 1994). Another condition for $\mathrm{N}_{2} \mathrm{O}$ formation is a $\mathrm{pH}$ below 7.3, at which nitrogen oxidoreductase is inhibited (Knowles, 1982).

Except for dissimilatory nitrate reduction, many aerobic and anaerobic bacteria are capable of assimilatory nitrate reduction to supply the cells with ammonia for growth (Eqs. 29 and 30). However, the enzymes for nitrate assimilation are expressed only at concentrations of ammonia $<1 \mathrm{mM}$. 


$$
\begin{aligned}
& \mathrm{NO}_{3}^{-} \underset{a}{\stackrel{2 e^{-}}{\longrightarrow}} \mathrm{NO}_{2}^{-} \underset{b}{\stackrel{2 e^{-}}{\longrightarrow}} \mathrm{HNO} \underset{b}{\stackrel{2 e^{-}}{\longrightarrow}} \mathrm{NH}_{2} \mathrm{OH} \underset{b}{\stackrel{2 e^{-}}{\longrightarrow}} \mathrm{NH}_{3} \\
& \mathrm{HNO}_{3}+8(\mathrm{H}) \rightarrow \mathrm{NH}_{4}^{+} \mathrm{OH}^{-}+2 \mathrm{H}_{2} \mathrm{O}
\end{aligned}
$$

Here, nitrate reductase B (enzyme $a$ in Eq. 29) reduces nitrate to nitrite, which is then reduced to ammonia by the nitrite reductase complex (enzyme b in Eq. 29). Whereas nitrate reduction by the oxygen-sensitive, membrane-bound enzyme nitrate reductase A conserves energy, no energy conservation is possible in the reaction catalyzed by the soluble enzyme nitrate reductase B, which is not repressed by oxygen. For details on the cell biology and the molecular basis of denitrification, please refer to Zumft (1997).

\section{3 .4}

\section{Combined Nitrification and Denitrification}

A strict separation of the reactions participating in aerobic, autotrophic nitrification and in anoxic, heterotrophic denitrification is not required, as concluded from $\mathrm{N}^{15}$. tracer experiments (Kuenen and Robertson, 1994). Autotrophic ammonia oxidizers seem to be able to produce $\mathrm{NO}, \mathrm{N}_{2} \mathrm{O}$, or $\mathrm{N}_{2}$ from nitrite if oxygen is limited, and ammonia as well as nitrite oxidizers can be isolated from anaerobic reactors (Kuenen and Robertson, 1994). Nitrosomonas europaea can use nitrite as an electron acceptor and pyruvate as an energy source under anoxic, denitrifying growth conditions (Abeliovich and Vonshak, 1992). In addition, several strains of Nitrobacter sp. were reported to denitrify during anoxic, heterotrophic growth (Bock et al., 1986).

Aerobic denitrification by Thiosphaera pantotropha was first described by Robertson and Kuenen (1984). T. pantotropha respires molecular oxygen and denitrifies nitrate simultaneously, provided that suitable electron acceptors are available. The conversion rate of acetate as electron donor with nitrate as electron acceptor was twice as high when the concentration of molecular oxygen was $<30 \%$ of air saturation compared to $30 \%-80 \%$ air saturation (Robertson et al., 1988). Respiration, simultaneous nitrification, and denitrification were observed in the presence of oxygen and ammonia. During heterotrophic denitrification by T. pantotropha, ammonia is first oxidized to hydroxylamine by an ammonia monooxygenase, with ubiquinone serving as electron donor. Hydroxylamine is subsequently oxidized to nitrite by a hydroxylamine oxidoreductase. During coupled nitrification-denitrification, 3 of the 4 electrons from the oxidation of hydroxylamine are used for reduction of nitrite to nitrogen and are not available to the electron transport reaction catalyzed by cytochrome oxidase. Regeneration of ubiquinone is mediated by electrons that are generated during oxidation of an organic substrate (heterotrophic nitrification).

Conversion rates of ammonia by heterotrophic nitrifiers such as T. pantotropha (Kuenen and Robertson, 1994) are smaller than those of autotrophic nitrifiers (35.4 for T. pantotropha versus $130-1550 \mathrm{nmol} \mathrm{NH}_{3} \mathrm{~min}^{-1} \mathrm{mg}^{-1}$ dry weight for Nitrosomonas sp.). If, however, the higher population density of heterotrophic nitrifiers, resulting from higher growth rates, is taken into consideration, the specific conversion rates are in a similar range. Heterotrophic nitrifiers can, in addition to their nit- 
rifying capability, denitrify nitrite or nitrate to molecular nitrogen. In many wastewater treatment plants autotrophic nitrifiers may exist, producing nitrite from ammonia under moderately aerobic conditions; the ammonia is then converted to nitrate and/or reduced to nitrogen by heterotrophic nitrifiers in the presence of a suitable carbon source. In practice, the only disadvantage of heterotrophic nitrification is more surplus sludge generation for final disposal.

\subsection{5}

\section{Anaerobic Ammonia Oxidation (Anammox ${ }^{\circledR}$ )}

To date, two anaerobic ammonia-oxidizing bacteria species have been isolated and preliminarily classified in the order Planctomycetales as candidatus Brocardia anammoxidans and candidatus Kuenenia stuttgartiensis. Under anaerobic conditions ammonia is oxidized to nitrite in membrane-bound intracytoplasmic anammoxosoms (Schmidt et al., 2003).

In the Anammox process ammonia is oxidized to nitrogen, with nitrite serving as electron acceptor (Van de Graaf et al., 1995). Use of $\mathrm{N}^{15}$ isotopes indicated that nitrite is reduced to hydroxylamine (Eq. 31), which then reacts with ammonia to yield hydrazine $\left(\mathrm{N}_{2} \mathrm{H}_{4}\right.$, Eq. 32). By oxidation of hydrazine to molecular nitrogen (Eq. 33), four reducing equivalents are generated, which are required for nitrite reduction to hydroxylamine (Van de Graaf et al., 1997).

$$
\begin{aligned}
& 2 \mathrm{HNO}_{2}+4 \mathrm{XH}_{2} \rightarrow 2 \mathrm{NH}_{2} \mathrm{OH}+2 \mathrm{H}_{2} \mathrm{O}+4 X \\
& 2 \mathrm{NH}_{2} \mathrm{OH}+2 \mathrm{NH}_{3} \rightarrow 2 \mathrm{~N}_{2} \mathrm{H}_{4}+2 \mathrm{H}_{2} \mathrm{O} \\
& 2 \mathrm{~N}_{2} \mathrm{H}_{4}+4 X \rightarrow 2 \mathrm{~N}_{2}+4 \mathrm{XH}_{2}
\end{aligned}
$$

Since the redox state is balanced in the above reactions, reducing equivalents for $\mathrm{CO}_{2}$ reduction by the autotrophic microorganisms must be generated by oxidation of nitrite to nitrate (Eq. 34):

$$
\mathrm{HNO}_{2}+\mathrm{H}_{2} \mathrm{O}+\mathrm{NAD} \rightarrow \mathrm{HNO}_{3}+\mathrm{NADH}_{2}
$$

Per mol of ammonia, $0.2 \mathrm{~mol}$ nitrate is generated and $20 \mathrm{mg}$ biomass is produced (Van de Graaf et al., 1996). The Anammox process seems to be suitable for nitrogen removal in ammonia-rich effluents of anaerobic reactors that are fed with wastewater rich in TKN compounds. Nitrogenous compounds can be eliminated from this wastewater by a combination of nitrification for nitrite supply and anaerobic ammonia oxidation (Strous et al., 1997). The process is sensitive to high, toxic nitrite concentrations of $70-180 \mathrm{mg} \mathrm{N} \mathrm{L}^{-1}$ (depending on the kind of biomass). Furthermore, due to the low growth rate of the anammox bacteria, a startup time of 100-150 days with activated sludge as inoculum seems to be necessary (Schmidt et al., 2003).

In oxygen-limited environments (e.g. oxic-anoxic interfaces of biofilms or sludge flocs) aerobic and anaerobic ammonia oxidizers are natural partners. The ammonia is oxidized to nitrite and concomitantly the oxygen level is decreased. The anammox bacteria disproportionate the nitrite and the remaining ammonia to $\mathrm{N}_{2}$. When am- 
monia is limited, the affinities of aerobic and anaerobic ammonia oxidizers may lead the natural partners to change to competitors (Schmidt et al., 2002). Other examples of 'uncontrolled' anammox activities were observed in different wastewater treatment plants with uncharacterized high ammonium losses.

\section{3 .6}

\section{New N-removal Processes}

The metabolic versatility of nitrogen-converting bacteria offers new concepts for nitrogen removal processes to treat wastewater. A partial nitrification of ammonia to nitrite (nitritation) would have the advantage of saving a significant amount of oxygen for the nitrification process, as compared to nitratation of ammonia. However, nitrite is toxic and must be kept below toxic concentrations. In a subsequent denitrification process, fewer reducing equivalents from the degradation of different carbon sources, which often are a limiting factor in wastewater treatment plants, are then required. In the SHARON process, which is a single reactor system for rapid ammonia oxidation to nitrite and subsequent denitrification of the nitrite with methanol, nitrite oxidizers that would generate nitrate are outcompeted by the slowly metabilizing ammonia oxidizers after a temperature shift toward higher temperatures, due to the higher temperature tolerance of the ammonia oxidizers, and by no sludge retention or sludge return in the reactor (Hellinga et al., 1998). Aeration was switched off periodically and denitrification of nitrite was initiated by adding methanol as a carbon source. The SHARON process in full scale was used to treat sludge liquor at the Rotterdam wastewater treatment plant (Mulder et al., 2001). The partial nitrification of ammonia to nitrite led to an ammonia/nitrite ratio that was suitable for a subsequent Anammox process in which nitrite was denitrified to $\mathrm{N}_{2}$ with ammonia instead of methanol as the electron donor. This process was finally established in full-scale at the Rotterdam wastewater treatment plant (Schmidt, 2003).

Partial ammonia oxidation to nitrite and anaerobic oxidation of ammonia in one aerated reactor is the concept behind the CANON process (completely autotrophic nitrogen removal over nitrite) (Van Lossdrecht and Jetten, 1997). Aerobic and anaerobic ammonia-oxidizing bacteria cooperate as long as the nitrifying bacteria consume oxygen and create anoxic conditions for the anaerobic ammonia-oxidizing bacteria.

Another possibility for removing ammonia in one single step without using an organic carbon source is the OLAND process (oxygen-limited nitrification and denitrification) (Kuai and Verstraete, 1998). Conversion of ammonia to $\mathrm{N}_{2}$ is catalyzed by aerobic nitrifiers and anaerobic granular sludge as a source of Planctomycetes including anaerobic ammonia-oxidizing bacteria (Pynaert et al., 2004).

Other nitrogen-removal processes also exist, such as the $\mathrm{NO}_{\mathrm{x}}$ process (simultaneous nitrification and denitrification of Nitrosomonas-like microorganisms under fully oxic conditions) and aerobic deammonification (conversion of ammonia to $\mathrm{N}_{2}$ and nitrate), which allow ammonia removal without COD. An overview of these new concepts was presented by Schmidt et al., 2003. 


\section{4}

\section{Enhanced Biological Phosphate Removal}

Based on an early observation that microorganisms take up more phosphate than required for cell growth, it was found that single cells accumulate polyphosphate in granules containing a few to several thousand phosphate units (Egli and Zehnder, 1994). Phosphate constitutes up to $12 \%$ of the cell weight of polyphosphate-accumulating bacteria, whereas bacteria that do not accumulate polyphosphate contain only 1\%-3\% phosphate (van Loosdrecht et al., 1997b). The accumulated polyphosphate is assumed to be an energy source for substrate assimilation during anaerobic growth conditions and poly- $\beta$-hydroxyalkanoate (PHA) synthesis. Evidence suggests that degradation of polyphosphate may be used to regulate intracellular $\mathrm{pH}$ under alkaline conditions (Seviour et al., 2003). For biological phosphate removal by 'luxury phosphate uptake', the polyphosphate-accumulating bacteria in wastewater have to be subjected in sequence to an anaerobic and an aerobic environment. All previous attempts to isolate polyphosphate-accumulating bacteria (culture-dependent approach) led to recovery of Acinetobacter sp. which belongs to the $\mathrm{\gamma}$-Proteobacteria and is the model organism for explanation of the polyphosphate accumulation mechanism found in textbooks. However, pure cultures of the polyphosphate-accumulating Acinetobacter sp. and wastewater communities seem to behave differently (van Loosdrecht et al., 1997a). A major discrepancy is that Acinetobacter sp. do not play a dominant role in activated sludge systems, as deduced from a survey using specific gene probes (Wagner et al., 1994). The culture-independent approach led to a mixed population for enhanced biological phosphorous removal (EBPR). The phosphorous-removing members ( $>10 \%$ of the total population) were assigned to the $\beta$-Proteobacteria (Rhodocylus group e.g. candidatus Accumulibacter phosphatis), $\alpha$-Proteobacteria and Actinobacteria (Microlunatus phosphoruvorus) and to members of the Cytophaga-Flexibacter-Bacteroides division (Seviour et al., 2003).

In Acinetobacter sp. polyphosphate accumulation is closely interconnected with poly- $\beta$-hydroxybutyrate (PHB) and glycogen metabolism (van Loosdrecht et al., 1997b). Under anaerobic conditions in the absence of nitrate, acetate is taken up by Acinetobacter cells, metabolized to $\beta$-hydroxybutyrate, polymerized to $\mathrm{PHB}$, and stored intracellularly in inclusion bodies. Reducing equivalents for PHB formation from acetate are made available by glycolysis of glucose units from stored glycogen or are alternatively formed by other microorganisms for EBPR in an anaerobically operating TCA cycle. The energy for polymerization comes from hydrolysis of the anhydride bonds of ATP and polyphosphate. To supply both the maintenance metabolism and the storage metabolism of Acinetobacter with sufficient energy under anaerobic conditions, anhydride bonds in polyphosphate are hydrolyzed, and inorganic phosphate is excreted (phosphate resolubilization) (Smolders et al., 1994). Stored glycogen in microorganisms for EBPR may also provide ATP for PHA synthesis. For storage of $1 \mathrm{mg}$ fatty acids, about $0.6 \mathrm{mg}$ orthophosphate is released (Danesh and Oleszkiewicz, 1997). Under aerobic conditions two situations may be prevalent. In wastewater that does not contain a suitable carbon source for respira- 
tion, Acinetobacter sp. hydrolyze $\mathrm{PHB}$, which is stored in the granules, and respire the $\beta$-hydroxybutyrate to gain energy for growth, maintenance, formation of glycogen, and polymerization of phosphate, which is taken up from the wastewater. In the presence of oxygen much more $P_{i}$ is taken up by Acinetobacter sp. from the activated sludge flora than is released under anaerobic conditions ('luxury uptake'). Danesh and Oleszkiewicz (1997) reported that approximately 6 to $9 \mathrm{mg}$ volatile fatty acids are required for biological removal of $1 \mathrm{mg}$ phosphorous.

In wastewater that contains suitable carbon sources for Acinetobacter sp., these carbon sources are partially oxidized by the TCA cycle and are partially used for PHB formation (Kuba et al., 1994). Since reducing equivalents are needed for PHB formation, less ATP is formed by oxidative phosphorylation. The lower ATP yield is compensated by the energy from hydrolysis of polyphosphate to $\mathrm{P}_{\mathrm{i}}$, which the cells use to form ADP from AMP. Two moles of ADP are disproportionated to AMP and ATP by adenylate kinase, and little $\mathrm{P}_{\mathrm{i}}$ is released into the medium.

Except for obligately aerobic bacteria of the genus Acinetobacter, nitrate-reducing bacteria compete with microorganisms for EBPR for organic substrates, e.g., volatile fatty acids such as acetate. Nitrate-reducing bacteria also can eliminate phosphate from the aqueous environment (Kerrn-Jespersen and Henze, 1993). The simultaneous presence of obligately aerobic bacteria and nitrate-reducing bacteria in activated sludge may explain why, in the presence of nitrate in the anaerobic phosphate resolubilization phase (oxygen absent), $\mathrm{P}_{\mathrm{i}}$ does not accumulate in the medium. The denitrifying, polyphosphate-accumulating bacteria apparently do not inhibit $P_{\mathrm{i}}$ excretion by Acinetobacter, but they take up phosphate and accumulate it as polyphosphate. This may explain why resolubilization of phosphate by degradation of stored polyphosphate is not always observed in wastewater treatment plants for biological phosphate removal. Another possibility may be the inhibitory effect of nitric oxide (Section 1.3) on adenylate kinase, which is involved in polyphosphate degradation in Acinetobacter sp. .

For biological phosphate accumulation, the ability of cells to store reserve material plays an essential role. Polymerization of substrates and storage in intracellular granules may offer the advantage that, at times of substrate shortage or in an environment with low concentrations of substrates (at low $k_{\mathrm{m}}$ values), such organisms can survive much better than other heterotrophic bacteria that do not have effective strategies for substrate storage.

Biological phosphate elimination is a highly effective process leading to final concentrations in the wastewater of $<0.1 \mathrm{mg} \mathrm{L}^{-1}$ phosphate. For optimal biological phosphate removal, the COD/P ratio in the wastewater should be about $20 \mathrm{~g}$ COD $\mathrm{g}^{-1}$ phosphate to permit good growth of the polyphosphate-accumulating bacteria. If biological phosphate elimination is used in combination with chemical precipitation, the minimum COD/P ratio should be $2 \mathrm{~g} \mathrm{COD} \mathrm{g}^{-1}$ phosphate (Smolders et al., 1996 ) in processes with or without separation of primary sludge. If most of the particulate COD is separated in a primary sedimentation pond, ferrous ions should be added to supplement the biological phosphate removal with chemical precipitation. If no presedimentation of sludge is available or the sedimentation efficiency is low, no ferrous ions have to be added (van Loosdrecht et al., 1997b). A detailed descrip- 
tion of the state of the art concerning biological phosphate elimination was given by Schön (1999).

Problems with the stability of the EBPR process in wastewater treatment plants were periodically reported. The reason for this may be the occurrence of microorganisms known as glycogen nonpolyphosphate-accumulating organisms (GAOs). These bacteria are selected under EBPR operation conditions (alternating anaerobic-aerobic phases during treatment) and compete with microorganisms for EBPR for the available volatile fatty acids (Blackall et al., 2002). Filipe et al. (2001) suggested an important role of $\mathrm{pH}$ during anaerobic and aerobic operation of reactors: growth of GAOs is favored at low $\mathrm{pH}$, but at a $\mathrm{pH}$ of 7-7.5 the microorganisms for EBPR outcompete the GAOs. Further research is required to elucidate conditions under which GAOs are inhibited and growth of EBPR biomass is promoted.

\section{5}

\section{Biological Removal, Biotransformation, and Biosorption of Metal lons from Contaminated Wastewater}

Whereas solid organic and inorganic material in wastewater or sludge can be removed by sedimentation, soluble organic pollutants and xenobiotics should be eliminated from the aqueous environment by microbial mineralization or anaerobic degradation to gaseous products, with a varying portion (5\%-50\%) being used as substrates for bacterial growth. Most of the inorganic components present in wastewater are soluble and are ionized. Trace amounts of many cations (e.g., $\mathrm{Na}^{+}, \mathrm{K}^{+}$, $\mathrm{Ca}^{2+}, \mathrm{Fe}^{2+}, \mathrm{Ni}^{2+}, \mathrm{Co}^{2+}, \mathrm{Mn}^{2+}, \mathrm{Zn}^{2+}$, etc.) and anions (e.g., $\mathrm{PO}_{4}^{3-}, \mathrm{Cl}^{-}, \mathrm{S}^{2-}$ ) are essential micronutrients for bacterial growth. Other cations such as ammonia may also be required for bacterial growth, but the surplus amount must be oxidized to nitrate, and the nitrate denitrified to gaseous nitrogen, for $\mathrm{N}$ elimination from wastewater. Under anaerobic conditions sulfate is reduced to sulfide, low amounts of which are required for growth of bacteria. The sulfide not required for growth is toxic for bacteria if present as $\mathrm{H}_{2} \mathrm{~S}$ in high concentrations. In anaerobic reactors at a slightly alkaline $\mathrm{pH}$, most of the sulfide is precipitated as heavy metal sulfides; then it is harmless to microorganisms and their environment. To support detoxification, heavy metal ions may also be precipitated chemically.

Metal ion contaminants in wastewater can be removed by microorganisms by either a direct or indirect influence on the redox state of the metal ions or through biosorption of metal ions on the cell surface (Lovley and Coates, 1997). Some microorganisms have also developed resistance mechanisms against toxic metals by changing the oxidation state without supporting anaerobic growth. Certain bacteria, yeasts, fungi, and algae can actively accumulate intracellular metal ions against a gradient. The process of bioaccumulation of metal ions depends on living, metabolically active cells, whereas biosorption is a passive, energy-independent process that can be mediated also by inactive cell material. Biosorption of metal ions includes mechanisms such as ion exchange, chelation, matrix entrapment, and surface sorption (Unz and Shuttleworth, 1996). After biosorption or active removal of metal ions 
from wastewater or contaminated soil, the heavy metal-containing biomass must be separated and incinerated or regenerated by desorption or remobilization of the metals. As an example of successful biosorption, wastewater from the galvanizing industry that contained $29 \mathrm{mg} \mathrm{L}^{-1} \mathrm{Zn}$ and $10.5 \mathrm{mg} \mathrm{L}^{-1} \mathrm{Fe}$ was purified in a threestage stirred-reactor cascade. With $15 \mathrm{~g}$ biomass, $7.5 \mathrm{~L}$ of wastewater was decontaminated (Brauckmann, 1997). The removal of metal ions by biologically catalyzed changes in the redox state is an alternative. The altered speciation (valence status) of metals can lead to precipitation, solubilization, or volatilization of the metal ions.

Many bacteria use metal ions as electron acceptors for anaerobic respiration. Examples are the reduction of $\mathrm{Fe}^{3+}, \mathrm{Cr}^{6+}, \mathrm{Mn}^{4+}, \mathrm{Se}^{6+}, \mathrm{As}^{5+}, \mathrm{Hg}^{2+}, \mathrm{Pb}^{2+}$, or $\mathrm{U}^{6+}$ (Table 1.6). The dissimilatory metal-reducing bacteria can use $\mathrm{H}_{2}$ or organic pollutants (e.g., xenobiotics) as electron donors and are capable of simultaneously removing organic and inorganic contaminants. Metal ions are reduced and precipitated by sulfide that is generated by sulfate-reducing bacteria.

Solubilization of most heavy metal precipitates is favored at acid $\mathrm{pH}$, which is the favorable $\mathrm{pH}$ for soil or sludge decontamination, whereas an alkaline $\mathrm{pH}$ is favorable for precipitation of heavy metal ions to decontaminate wastewater.

An example of the formation of precipitates or soluble compounds at different redox states occur in ferrous and manganese compounds. Under aerobic conditions $\mathrm{Fe}(\mathrm{III})$ (ferric iron) and $\mathrm{Mn}$ (IV) ions form insoluble Fe(III) and $\mathrm{Mn}$ (IV) oxides or hydroxides, but under anaerobic conditions they form soluble Fe(II) compounds (ferrous iron) or $\mathrm{Mn}(\mathrm{II})$ compounds. Most organisms that grow with energy conserved during reduction of $\mathrm{Fe}(\mathrm{III})$ or $\mathrm{Mn}(\mathrm{IV})$ are members of the Geobacteriaceae. Transfer of electrons from the terminal reductase, localized in the outer membrane or at the

Table 1.6 Metals as electron acceptors for anaerobic respiration.

\begin{tabular}{|c|c|c|}
\hline Reaction & Microorganism & Reference \\
\hline $2 \mathrm{Fe}^{3+}+\mathrm{H}_{2} \leftrightarrow 2 \mathrm{Fe}^{2+}+2 \mathrm{H}^{+}$ & $\begin{array}{l}\text { Geobacter metallireducens } \\
\text { Pelobacter carbinolicus }\end{array}$ & $\begin{array}{l}\text { Lovley and Lonergan (1990) } \\
\text { Lovley et al. (1995) }\end{array}$ \\
\hline $\mathrm{Mn}^{4+}+\mathrm{H}_{2} \leftrightarrow \mathrm{Mn}^{2+}+2 \mathrm{H}^{+}$ & $\begin{array}{l}\text { Geobacter metallireducens } \\
\text { mixed culture }\end{array}$ & $\begin{array}{l}\text { Lovley (1991) } \\
\text { Langenhoff et al. (1997) }\end{array}$ \\
\hline $2 \mathrm{Cr}^{6+}+3 \mathrm{H}_{2} \leftrightarrow 2 \mathrm{Cr}^{3+}+6 \mathrm{H}^{+}$ & $\begin{array}{l}\text { Desulfovibrio vulgaris } \\
\text { Bacillus strain QC1-2 }\end{array}$ & $\begin{array}{l}\text { Lovley and Phillips (1994) } \\
\text { Campos et al. (1995) }\end{array}$ \\
\hline $\mathrm{Se}^{6+}+\mathrm{H}_{2} \leftrightarrow \mathrm{Se}^{4+}+2 \mathrm{H}^{+}$ & $\begin{array}{l}\text { Thauera selenatis } \\
\text { strains SES-1; SES-3 }\end{array}$ & Macy et al. (1993) \\
\hline $\mathrm{Se}^{6+}+3 \mathrm{H}_{2} \leftrightarrow \mathrm{Se}^{0}+6 \mathrm{H}^{+}$ & & Oremland et al. (1989) \\
\hline $\mathrm{Te}^{4+}+2 \mathrm{H}_{2} \leftrightarrow \mathrm{Te}^{0}+4 \mathrm{H}^{+}$ & Schizosaccharomyces pombe & Smith (1974) \\
\hline $\mathrm{Pb}^{2+}+\mathrm{H}_{2} \leftrightarrow \mathrm{Pb}^{0}+2 \mathrm{H}^{+}$ & Pseudomonas maltophila & Lovley (1995) \\
\hline $\mathrm{As}^{5+}+\mathrm{H}_{2} \leftrightarrow \mathrm{As}^{3+}+2 \mathrm{H}^{+}$ & Geospirillum arsenophilus & Ahmann et al. (1994) \\
\hline $\mathrm{Hg}^{2+}+\mathrm{H}_{2} \leftrightarrow \mathrm{Hg}^{0}+2 \mathrm{H}^{+}$ & $\begin{array}{l}\text { Escherichia coli } \\
\text { Thiobacillus ferrooxidans }\end{array}$ & Robinson and Tuovinen (1984) \\
\hline $\mathrm{U}^{6+}+\mathrm{H}_{2} \leftrightarrow \mathrm{U}^{4+}+2 \mathrm{H}^{+}$ & Shewanella putrefaciens & Lovley et al. (1991) \\
\hline
\end{tabular}


cell surface, to the insoluble Fe(III) or Mn(IV) oxides outside the cells can proceed either in a direct way (contact between the oxides and the cells) or by 'soluble electron shuttles' (e.g., by humic substances) between the metal-reducing microorganism and the mineral (Lloyd, 2003). Since Fe is an essential element for microorganisms, aerobic bacteria must excrete siderophores, which bind $\mathrm{Fe}^{3+}$ to their phenolate or hydroxamate moiety and supply the cells with soluble $\mathrm{Fe}^{2+}$. To accelerate $\mathrm{Fe}^{3+}$ reduction in biotechnological processes, the chelator nitrilotriacetic acid can be added. In addition to their use in synthesis of cell components (e.g., cytochromes, ferredoxin, etc.), $\mathrm{Fe}^{2+}$ salts can be electron donors for nitrate reduction (Straub et al., 1996).

The reduction of $\mathrm{Hg}^{2+}$ to metallic $\mathrm{Hg}$ by Escherichia coli or Thiobacillus ferrooxidans facilitates $\mathrm{Hg}$ separation and prevents methylation reactions under aerobic or sulfate-reducing conditions. The mechanism includes nonenzymatic transfer of methyl groups from methylcobalamin to $\mathrm{Hg}^{2+}$ to form methyl mercury or dimethyl mercury, which are both neurotoxins and become enriched in the food chain. Selenium and arsenic can be transformed microbiologically by methylation to dimethyl selenide or to di- or trimethyl arsine in a volatile form. Methylated arsenic compounds are less toxic than nonmethylated arsenic compounds (White et al., 1997).

Changing the redox state of natural and anthropogenic radionuclides by metal-reducing microorganisms offers a possibility to control their solubility and mobility by converting, e.g., $\mathrm{U}^{6+}$ to $\mathrm{U}^{4+}, \mathrm{Pu}^{5+}$ to $\mathrm{Pu}^{4+}$, or $\mathrm{Np}^{5+}$ to $\mathrm{Np}^{4+}$. The tetravalent metals can be removed by chelators (e.g., EDTA) or by immobilization onto biomass from the contaminated environment (Lloyd, 2003).

In contrast to bacteria, fungi are capable of leaching soluble as well as insoluble metal salts, because they excrete organic acids such as citric acid, fumaric acid, lactic acid, gluconic acid, oxalic acid, or malic acid, which dissolve metal salts and form complexes with the metal ions. The leaching efficiency depends on the soil microflora. Some soil microorganisms seem to be able to degrade the carbon skeleton of the metal-organic complex and thus immobilize the metal ions again (Brynhildsen and Rosswall, 1997).

Mixed bacterial cultures or Wolinella succinogenes use perchlorate or chlorate as electron acceptors for respiration (Wallace et al., 1996; van Ginkel et al., 1995) and thus detoxify these chemicals.

\subsection{1}

\section{Sulfate Reduction and Metal Ion Precipitation}

Sulfate-reducing bacteria are biotechnologically relevant to sulfate removal or heavy metal precipitation in wastewater or waste and to the elimination of $\mathrm{SO}_{2}$ during offgas purification. An overview of applications of sulfate-reducing microorganisms in environmental biotechnology is given by Lens et al. (2002). Sulfate is the terminal electron acceptor and is reduced to sulfide, with reducing equivalents derived from the degradation of lactic acid or many other organic compounds (Widdel, 1988). Alternatively, some sulfate reducers can also use molecular hydrogen. Sulfate reducers gain energy in an anaerobic electron transport chain (Hansen, 1994), leading to sulfide, a weak dibasic acid, which dissociates according to Eq. 35. 


$$
\begin{aligned}
& \mathrm{H}_{2} \mathrm{~S} \stackrel{K_{1}}{\leftrightarrow} \mathrm{H}^{+}+\mathrm{HS}^{-} \stackrel{K_{2}}{\longleftrightarrow} 2 \mathrm{H}^{+}+\mathrm{S}^{2-} \\
& K_{1}=1.02 \times 10^{-7}, K_{2}=1.3 \times 10^{-13}\left(25^{\circ} \mathrm{C}\right)
\end{aligned}
$$

The total dissociation is described by Eq. 36:

$$
K=\frac{\left[\mathrm{H}^{+}\right]\left[\mathrm{S}^{2-}\right]}{\left[\mathrm{H}_{2} \mathrm{~S}\right]}=K_{1} K_{2}=1.3 \times 10^{-20}
$$

For precipitation of heavy metal ions, sulfide ions are necessary (Eq. 37):

$$
\mathrm{Me}^{2+}+\mathrm{S}^{2-} \leftrightarrow \mathrm{MeS} \text { (or) } 2 \mathrm{Me}^{+}+\mathrm{S}^{2-} \leftrightarrow \mathrm{Me}_{2} \mathrm{~S}
$$

The concentration of sulfide is $\mathrm{pH}$-dependent. At acid $\mathrm{pH}$ only those metal sulfides of very low solubility can be precipitated. Thus, at acid $\mathrm{pH}, \mathrm{HgS}, \mathrm{As}_{2} \mathrm{~S}_{3}, \mathrm{CdS}$, $\mathrm{CuS}$, and $\mathrm{PbS}$ form precipitates, whereas at a more alkaline $\mathrm{pH}, \mathrm{ZnS}, \mathrm{FeS}$, NiS, and $\mathrm{MnS}$ form precipitates. $\mathrm{Al}_{2} \mathrm{~S}_{3}$ and $\mathrm{Cr}_{2} \mathrm{~S}_{3}$ are water soluble and cannot be removed by precipitation or sedimentation. Zinc removal from zinc-contaminated groundwater by microbial sulfate reduction and zinc sulfide precipitation in a 9- $\mathrm{m}^{3}$ sludge blanket reactor was demonstrated and has been transferred to a full scale reactor of $1800 \mathrm{~m}^{3}$ (White and Gadd, 1996).

\section{6}

\section{Aerobic and Anaerobic Degradation of Xenobiotics}

Except for pesticides and insecticides, which are widely used in horticulture and farming and small amounts of which are washed into the groundwater, many xenobiotics are spilled in the environment, by spot contamination or contamination of large areas. Biological remediation of soil and groundwater contaminated with gasoline (e.g., Yerushalmi and Guiot, 1998) and the volatile fractions of diesel oil (e.g., Greiff et al., 1998), even at low temperatures (Margesin and Schinner, 1998), seems to be no problem. Results of many laboratory and field studies with a variety of substances are available (e.g., Arendt et al., 1995; Hinchee et al., 1995a, b; Kreysa and Wiesner, 1996). Except for studies in complex field or wastewater environments, many xenobiotics can be degraded by aerobic or anaerobic pure or defined mixed cultures (Table 1.7). These include monoaromatic and polyaromatic substances with or without chloro substituents. Whereas the two-ring compound naphthalene is relatively easily degradable by Pseudomonas sp. and Rhodococcus sp., the four-ring compounds fluoranthene and pyrene are much less degradable by Rhodococcus sp. (Bouchez et al., 1996). Aromatic compounds such as phenol and benzoic acid are degradable by mixed consortia at rates up to $1 \mathrm{~g} \mathrm{~L}^{-1} \mathrm{~d}^{-1}$ in either the presence or absence of oxygen (Mörsen and Rehm, 1987; Knoll and Winter, 1987; Kobayashi et al., 1989). A potent population is required, which can be obtained by preincubation. Even PCP is biodegradable by a methanogenic mixed culture from UASB granules (Juteau et al., 1995; Wu et al., 1993; Kennes et al., 1996). Some pure cultures and mixed cultures are capable of dechlorinating aromatic or aliphatic compounds 
(Table 1.7, second part). As for the aerobic and anaerobic degradation of phenol, the rates of dechlorination of 2-chlorophenol under aerobic and anaerobic conditions are the same order of magnitude, 102 and $128 \mathrm{mg} \mathrm{L}^{-1} \mathrm{~d}^{-1}$, respectively (Kafkewitz et al., 1996; Dietrich and Winter, 1990). A pure culture of Pseudomonas pickettii was used for aerobic dechlorination, but for anaerobic degradation a mixed culture was used. The main problem in degradation of xenobiotic compounds in wastewater is a too short residence time in the reactors, which does not allow selection or adaptation of bacteria for dechlorination or degradation. Only if a permanent pollution is prevalent, the degradation potential may develop with time. Alternatively, biofilm reactors should be used to enrich dechlorinating and xenobiotic-degrading bacteria.

Table 1.7 Aerobic and anaerobic degradation or dechlorination of xenobiotics.

\begin{tabular}{|c|c|c|c|}
\hline $\begin{array}{l}\text { Reaction } \\
\text { Substance }\end{array}$ & $\begin{array}{l}\text { Rate } \\
\left(m g L^{-1} d^{-1}\right)\end{array}$ & Microorganisms & Reference \\
\hline \multicolumn{4}{|l|}{ Aerobic degradation } \\
\hline $\begin{array}{l}\text { 2-Hydroxy- } \\
\text { benzothiazole }\end{array}$ & 138 & Rhodococcus rhodochrous & $\begin{array}{l}\text { De Wever et al. } \\
(1997)\end{array}$ \\
\hline Naphthalene & 57 & $\begin{array}{l}\text { Pseudomonas sp. } \\
\text { Rhodococcus sp. }\end{array}$ & Bouchez et al. (1996) \\
\hline Fluoranthene & 6.6 & Rhodococcus sp. & Bouchez et al. (1996) \\
\hline Pyrene & 6.6 & Rhodococcus sp. & Bouchez et al. (1996) \\
\hline Pyrene & 0.56 & Mycobacterium flavescens & $\begin{array}{l}\text { Dean-Ross and } \\
\text { Cerniglia (1996) }\end{array}$ \\
\hline Toluene & 57 & Pseudomonas putida & $\begin{array}{l}\text { Heald and Jenkins } \\
\text { (1996) }\end{array}$ \\
\hline Phenol & 188 & Bacillus sp. A2 & Mutzel et al. (1996) \\
\hline Phenol & 1000 & mixed immobilized culture & $\begin{array}{l}\text { Mörsen and Rehm } \\
\text { (1987) }\end{array}$ \\
\hline Cresol $(o, m, p)$ & 259 & mixed immobilized culture & $\begin{array}{l}\text { Mörsen and Rehm } \\
\text { (1987) }\end{array}$ \\
\hline $\begin{array}{l}\text { 2,4-Diphenoxy-acetic } \\
\text { acid }\end{array}$ & 33 & $\begin{array}{l}\text { Alcaligenes eutrophus } \\
\text { JMP134 (pJP4) }^{\mathrm{b}}\end{array}$ & $\begin{array}{l}\text { Valenzuela et al. } \\
\text { (1997) }\end{array}$ \\
\hline 2,4,6-Trichlorophenol & 15 & JMP134 (pJP4) ${ }^{\mathrm{b}}$ & Valenzuela et al. (1997) \\
\hline \multicolumn{4}{|l|}{ Anaerobic degradation } \\
\hline $\begin{array}{l}\text { Pentachlorophenol } \\
\text { (PCP) }\end{array}$ & 107 & $\begin{array}{l}\text { methanogenic mixed culture, } \\
\text { fixed film reactor }\end{array}$ & Juteau et al. (1995) \\
\hline PCP & 90 & $\begin{array}{l}\text { methanogenic mixed culture } \\
\text { UASB }\end{array}$ & Wu et al. (1993) \\
\hline PCP & 4.4 & methanogenic granules & Kennes et al. (1996) \\
\hline PCP & 22.7 & methanogenic mixed culture & Juteau et al. (1995) \\
\hline
\end{tabular}


Table 1.7 Aerobic and anaerobic degradation or dechlorination of xenobiotics (Continued).

\begin{tabular}{|c|c|c|}
\hline $\begin{array}{l}\text { Reaction } \\
\text { Substance }\end{array}$ & $\begin{array}{l}\text { Rate } \\
\left(m g L^{-1} d^{-1}\right)\end{array}$ & Microorganisms \\
\hline Benzene & 0.029 & sulfate-reducing mixed culture \\
\hline Phenol & 1000 & methanogenic mixed culture \\
\hline Phenol & 31 & syntrophic mixed culture \\
\hline Phenol & 200 & syntrophic mixed culture \\
\hline Benzoic acid & 600 & syntrophic culture \\
\hline Toluene & $0.1-1.5$ & sulfate-reducing mixed culture \\
\hline Toluene & 4.6 & methanogenic mixed culture \\
\hline Xylene & $0.1-1.5$ & sulfate-reducing mixed culture \\
\hline Xylene & 5.3 & methanogenic mixed culture \\
\hline
\end{tabular}

Reference

Edwards and

Gribić-Galic (1992)

Knoll and Winter

(1987)

Knoll and Winter

(1989)

Kobayashi et al. (1989)

Kobayashi et al. (1989)

Edwards et al. (1992)

Edwards and

Gribić-Galic (1994)

Edwards et al. (1992)

Edwards and

Gribić-Galic (1992)

\section{Aerobic Dechlorination}

2-Chlorophenol

Pseudomonas pickettii

Kafkewitz et al. (1996)

4-Chlorophenol

Pseudomonas pickettii

1,3-Dichloro-2-

Pseudomonas pickettii

Kafkewitz et al. (1996)

propanol

Tetrachloroethene

35.8 total $^{\mathrm{c}}$ anaerobic mixed culture

Kafkewitz et al.

(1996)

Wu et al. (1995)

\section{Anaerobic Dechlorination}

2,6-Dichlorophenol

methanogenic mixed culture

Dietrich and Winter

4-Chlorophenol

0.43

2-Chlorophenol

2-Chlorophenol

1.66

6.08

3-Chlorobenzoate

29.9

3-Chloro-4-hydroxybenzoate

Polychlorinated biphenyls (PCBs):

$\begin{array}{clll}\text { 2,3,4,5,6-CB } & \text { 0.24 total } & \text { methanogenic granules } & \text { Natarajan et al. (1996) } \\ \text { 2,3,4,5-CB } & 0.393,5-\mathrm{CB}^{\mathrm{c}} & \text { anaerobic sediments } & \text { Berkaw et al. (1996) } \\ \text { 2,3,4,6-CB } & 13.3 \text { tri-CB } \mathrm{CB}^{\mathrm{c}} & \text { anaerobic sediment } & \text { Wu et al. (1996) } \\ \text { Tetrachloroethene } & 6.13 & \text { methanogenic granules } & \begin{array}{l}\text { Christiansen et al. } \\ \text { (1997) }\end{array}\end{array}$

anaerobic mixed culture

(1990)

Häggblom (1998)

Dietrich and Winter (1990)

Kuo and Sharak

Genthner (1996)

Kuo and Sharak Genthner (1996)

Sanford et al. (1996)

chlororespirans 
Table 1.7 Aerobic and anaerobic degradation or dechlorination of xenobiotics (Continued).

\begin{tabular}{llll}
\hline $\begin{array}{l}\text { Reaction } \\
\text { Substance }\end{array}$ & $\begin{array}{l}\text { Rate } \\
\left(\mathbf{m g ~ L}^{-1} \mathbf{d}^{-1}\right)\end{array}$ & Microorganisms & Reference \\
\hline Tetrachloroethene & $\begin{array}{l}1.64 \\
\text { dichloro- } \\
\text { ethene }\end{array}$ & strain TT 4B & $\begin{array}{l}\text { Krumholz et al. } \\
(1996)\end{array}$ \\
Tetrachloroethene & $\begin{array}{l}2.05 \\
\text { dichloro- } \\
\text { ethene }\end{array}$ & strain MS-1 & $\begin{array}{l}\text { Sharma and } \\
\text { McCarty (1996) }\end{array}$ \\
DCB, TCB, TeCB & $\begin{array}{l}\text { cethenic mixed culture } \\
\text { 1.24 }\end{array}$ & $\begin{array}{l}\text { Middeldorp et al. } \\
(1997)\end{array}$ \\
\hline
\end{tabular}

a Alcaligenes eutrophus $=$ Ralstonia eutropha.

b pJP4 = 2,4-dichlorophenoxy acetic acid-degrading plasmid.

c Dehalogenation product: total dehalogenation or partial dehalogenation to the corresponding dehalogenation product.

d 2,3,4,5,6-CB $=2,3,4,5,6$-chlorinated biphenyls.

e $\mathrm{DCB}=$ dichlorobenzene, $\mathrm{TCB}=$ trichlorobenzene, $\mathrm{TeCB}=$ tetrachlorobenzene.

\section{7}

\section{Bioaugmentation in Wastewater Treatment Plants for Degradation of Xenobiotics}

In biotechnology and pharmacology, mutants of bacteria or fungi or genetically engineered organisms are widely used in the production of citric acid, gluconic acid, ascorbate, and pharmaceuticals such as penicillin, insulin, and blood coagulation factors. Bacteria and fungi have also been adapted or genetically transformed for soil remediation (Atlas, 1981; Margesin and Schinner, 1997, Korda et al., 1997; Megharai et al., 1997). For wastewater and sludge stabilization however, successful use of genetically modified bacteria or of bacteria that can serve as donors for plasmids encoding degradative enzymes has been rather rare (van Limbergen et al., 1998). Usually, natural selection of the most suitable microorganisms from a complex flora, simply by adapting process parameters, is used. The limited reports on successful bioengineering for wastewater treatment may result from any of several factors:

- The plasmids were unstable or the genes are not expressed in the new environment.

- Inoculated strains did not survive or, if they survived, metabolic activity was too low for successful competition with autochthonous strains.

- Inoculated strains, serving as a gene source, survived, but other strains were not competent for gene transfer.

- Wastewaters normally contain a complex spectrum of carbon sources that are better than xenobiotics, and so organisms do not express genes for degrading xenobiotics.

To increase the survival potential in wastewater, a selected flora should have the desired degradative ability, tolerance to cocontaminants, and a natural spatial and tem- 
porary abundance (van der Gast et al., 2003). Another possibility would be to add organisms containing plasmids having a broad host range, permitting conjugation and DNA exchange between different species or genera of bacteria.

To enhance degradation of organic compounds in activated sludge or by a biofilm, selected specialized bacteria, genetically modified bacteria, or bacteria as plasmid donors for degradative pathways can be added (McClure et al., 1991; Frank et al., 1996). Plasmid exchange from donor to recipient cells would be advantageous to the recipient bacteria, because the plasmids harbor genes whose products function in pathways for xenobiotic degradation, which would thus extend the substrate spectrum of the recipients. The transfer of naturally occurring mercury-resistance plasmids between Pseudomonas strains in biofilms was shown to occur rapidly (Bale et al., 1988).

Selvaratnam et al. (1997) added a phenol-degrading strain of Pseudomonas putida to an activated sludge SBR reactor, which had removed $170 \mathrm{mg} \mathrm{L}^{-1}$ of phenol before being augmented with the Pseudomonas putida strain. Whereas the original phenoldegrading activity was partially lost in the nonaugmented reactor upon further operation, the augmented reactor almost completely degraded the phenol. A more convincing approach would have been to use non-phenol-degrading activated sludge for this experiment, although the survival of the catabolic plasmid $d m p N$ of Pseudomonas putida and its expression in the reactor biomass was demonstrated for $44 \mathrm{~d}$ by molecular biology techniques under steady-state conditions in the laboratory.

Successful bioaugmentation experiments in an upflow anaerobic sludge blanket reactor were reported by Ahring et al. (1992), who introduced a suspension of a pure culture of Desulfomonile tiedjei or a three-member consortium into an UASB reactor. They observed a rapid increase in the dehalogenation of 3-chlorobenzoate, whereas nonamended parallel incubations had no dehalogenating activity. Even after several months at $0.5-\mathrm{d}$ hydraulic residence time, which was shorter than the generation time of Desulfomonile tiedjei, dehalogenating activity was still observed, and Desulfomonile tiedjei could be found within the biofilm by the use of antibody probes. More recently, an UASB reactor was supplemented with Dehalospirillum multivorans to improve its dehalogenating activity (Hörber et al., 1998). In contrast, Margesin and Schinner (1998) found, for biological decontamination of fuel-contaminated wastewater, that stimulation of the autochthonous flora by adding a mineral mix enhanced biodegradation to a larger extent than bioaugmentation with a cold-adapted mixed inoculum containing Pseudomonas sp. and Arthrobacter sp.

Bioaugmentation with a complex inoculum, which naturally occurs in metalwork fluids and contains strains of Clavibacter sp., Rhodococcus sp., Methylobacterium sp. and Pseudomonas sp. is very effective in degrading COD in wastewater. The augmented consortium degraded $67 \%$ of the COD $\left(48 \mathrm{~g} \mathrm{~L}^{-1}\right)$ and was therefore $50 \%-60 \%$ more effective than the indigenous flora. In-situ analysis showed that $100 \mathrm{~h}$ after the introduction, the augmented consortium constituted more than $90 \%$ of the population (van der Gast et al., 2003).

Degradation of many xenobiotics in anaerobic or aerobic pure cultures or complex ecosystems has been demonstrated. Whereas for 'intrinsic sanitation' of polluted soil, the time is not limited, so long as the pollutants are adsorbed tightly to the 
soil matrix, degradation of xenobiotics in wastewater must be completed during the residence time in the treatment system. Thus, merely the presence of a degradation potential within a wastewater ecosystem is not sufficient, but degradation rates must be high enough, and degradation must be faster than the residence time of bacteria in suspended systems. Supplementation with microorganisms as a potential tool to increase the degradation speed or to increase the degradation potential in wastewater cannot in general be considered a state-of-the-art procedure yet.

\section{References}

Abeliovich, A., Vonshak, A., Anaerobic metabolism of Nitrosomonas europaea, Arch. Microbiol. 1992, 158, 267-270.

Ahmann, D., Roberts, A. L., Krumholz, L. R., Morel, F. M. M., Microbe grows by reducing arsenic, Nature 1994, 371, 750.

Ahring, B. K., Perspectives for anaerobic digestion. In: Advances in Biochemical Engineering/Biotechnology, vol 81, Biomethanation I (Ahring, B. K., ed.), pp. 1-30. New York 2003: Springer-Verlag.

Ahring, B. K., Christiansen, N., Mathari, I., Hendriksen, H. V., Macario, A. J. L., DeMacario, E. C., Introduction of de novo bioremediation ability, aryl reductive dechlorination, into anaerobic granular sludge by inoculation of sludge with Desulfomonile tiedjei, Appl. Environ. Microbiol. 1992, 58, 3677-3682.

Arendt, F., Bosmann, R., van den Brink, W. J. (eds.), Contaminated Soil '95, Vol. 1. Dordrecht 1995: Kluwer.

Atlas, R. M., Microbial degradation of petroleum hydrocarbons: an environmental perspective, Microbiol. Rev. 1981, 45, 180-209.

ATV, Arbeitsbericht Fachausschuss 7.5: Geschwindigkeitsbestimmende Schritte beim anaeroben Abbau von organischen Verbindungen in Abwässern, Korrespondenz Abwasser 1994, 1, 101-107.

Bale, M. J., Day, M. J., Fry, J. C., Novel method for studying plasmid transfer in undisturbed river epilithon, Appl. Environ. Microbiol. 1988, 54, 2756-2758.

Be'guin, P., Aubert, J.-P., The biological degradation of cellulose, FEMS Microbiol. Rev. 1994, 13, 25-58.

Berkaw, M., Sowers, K. R., May, H. D., Anaerobic ortho dechlorination of polychlorinated biphenyls by estuarine sediment from Baltimore Harbor, Appl. Environ. Microbiol. 1996, 62, 2534-2539.

Bernet, N., Habouzit, F., Moletta, R., Use of an industrial effluent as a carbon source for denitrification of a high-strength wastewater, Appl. Microbiol. Biotechnol. 1996, 46, 92-97.

Blackall, L. L., Crocetti, G. R., Saunders, A. M., Bond, P. L., A review and update of the microbiology of enhanced biological phosphorus removal in wastewater treatment plants. Antonie van Leeuwenhoek 2002, 81, 681-691. Bleicher, K., Winter, J., Formate production and utilization by methanogens and by sludge consortia: interference with the concept of interspecies formate transfer, Appl. Microbiol. Biotechnol. 1994, 40, 910-915.

Bleicher, K., Zellner, G., Winter, J., Growth of methanogens on cyclopentanol/ $/ \mathrm{CO}_{2}$ and specificity of alcohol dehydrogenase, FEMS Microbiol. Lett. 1989, 59, 307-312.

Bock, E., Koops, H.-P., Harms, H., Cell biology of nitrifying bacteria, in: Nitrification (Prosser, J. I., ed.), pp. 17-38. Oxford 1986: IRL Press.

Boone, D. R., Johnson, R. L., Liu, Y., Diffusion of the interspecies electron carriers $\mathrm{H}_{2}$ and formate in methanogenic ecosystems, and applications in the measurement of $K_{\mathrm{M}}$ for $\mathrm{H}_{2}$ and formate uptake, Appl. Environ. Microbiol. 1989, 55, 1735-1741.

Bouchez, M., Blanchet, D., Vandecasteele, J.P., The microbial fate of polycyclic aromatic hydrocarbons: carbon and oxygen balances for bacterial degradation of model compounds, Appl. Microbiol. Biotechnol. 1996, 45, 556-561.

Brauckmann, B., Mikrobielle Extraktion von Schwermetallen aus Industrieabwässern, Wasser Boden 1997, 49, 55-58. 
Broughton, M. J., Thiele, J., Birch, E. J., Cohen, A., Anaerobic batch digestion of sheep tallow, Water Res. 1998, 32, 1323-1428.

Bryant, M. P., Microbial methane production: theoretical aspects, J. Anim. Sci. 1979, 48, 193- 201.

Brynhildsen, L., Rosswall, T., Effects of metals on the microbial mineralization of organic acids, Water Air Soil Poll. 1997, 94, 45-57.

Buchauer, K., Zur Kinetik der anaeroben Hydrolyse und Fermentation von Abwasser, Österr. Wasser- und Abfallwirtsch. 1997, 49, 69-75.

Buchholz, K., Stoppock, E., Emmerich, R., Untersuchungen zur Biogasgewinnung aus Rübenpreßschnitzeln, Zuckerindustrie 1986, 111, 873-845.

Buchholz, K., Stoppock, E., Emmerich, R., Kinetics of anaerobic hydrolysis of solid material, 5th Int. Symp. Anaerobic Digestion, Poster papers 15-18, (Tilche, A., Rozzi, A., eds.). Bologna 1988: Monduzzi Editore.

Buswell, A. M., Mueller, H. F., Mechanism of methane fermentation, Ind. Eng. Chem. 1952, 44, 550-552.

Buswell, A. M., Neave, S. L., Laboratory studies on sludge digestion III, State Water Surv. Bull. 1930, 30, 1-84.

Buswell, A. M., Sollo, F. W., The mechanism of methane fermentation, J. Am. Chem. Soc. 1948, 7, 1778-1780.

Campos, J., Martinez-Pacheco, M., Cervantes, C., Hexavalent-chromium reduction by a chromate-resistant Bacillus sp. strain, Antonie von Leeuwenhoek 1995, 68, 203-208. Christiansen, N., Christensen, S. R., Arvin, E., Ahring, B. K., Transformation of tetrachloroethene in an upflow anaerobic sludge blanket reactor, Appl. Microbiol. Biotechnol. 1997, 47, 91-94.

Colberg, P. J., Anaerobic microbial degradation of cellulose, lignin, oligolignols and monoaromatic lignin derivatives, in: Biology of Anaerobic Microorganisms. Wiley Series in Ecological and Applied Microbiology (Zehnder, A. J. B., ed.). New York 1988: Wiley.

Colberg, P. J., Young, L. J., Anaerobic degradation of soluble fractions of $\left({ }^{14} \mathrm{C}\right.$-lignin $)$ lignocellulose, Appl. Microbiol. Biotechnol. $1985,49,345-349$.

Conrad, R., Soil microorganisms as controllers of the atmospheric trace gases $\left(\mathrm{H}_{2}, \mathrm{CO}\right.$,
$\mathrm{CH}_{4}, \mathrm{OCS}, \mathrm{N}_{2} \mathrm{O}$, and NO), Microbiol. Rev. 1996, 60, 609-640.

Coughlan, M. P., Mayer, F., The cellulose-decomposing bacteria and their enzymes, in: The Prokaryotes - A Handbook on the Biology of Bacteria: Ecophysiology, Isolation, Identification, Applications, (Vol. 1) (Ballows, A., Trüper, H. G., Dworkin, M., Harder, W., Schleifer, K.-H., eds.), pp. 461-516. New York 1991: Springer-Verlag.

Danesh, S., Oleszkiewicz, J. A., Volatile fatty acid production and uptake in biological nutrient removal systems with process separation, Water Environ. Res. 1997, 69, 1106-1111. Dean-Ross, D., Cerniglia, C. E., Degradation of pyrene by Mycobacterium flavescens, Appl. Microbiol. Biotechnol. 1996, 46, 307-312.

De Bok, F. A. M., Plugge, C. M., Stams, A. J. M., Interspecies electron transfer in methanogenic propionate degrading consortia, Water Res. 2004, 38, 1369-1375.

De Wever, H., De Cort, S., Noots, I., Verachtert, H., Isolation and characterization of Rhodococcus rhodochrous for the degradation of the wastewater component 2-hydroxybenzothiazole, Appl. Microbiol. Biotechnol. 1997, 47, 458-461.

Dietrich, G., Winter, J., Anaerobic degradation of chlorophenol by an enrichment culture, Appl. Microbiol. Biotechnol. 1990, 34, 253-258. Dolfing, J., The microbial logic behind the prevalence of incomplete oxidation of organic compounds by acetogenic bacteria in methanogenic environments, Microb. Ecol. 2001, 41, 83-89.

Edwards, E. A., Gribić-Galic, D., Complete mineralization of benzene by aquifer microorganisms under strictly anaerobic conditions, Appl. Environ. Microbiol. 1992, 58, 2663-2666.

Edwards, E. A., Gribić-Galic, D., Anaerobic degradation of toluene and $o$-xylene by a methanogenic consortium, Appl. Environ. Microbiol. 1994, 60, 313-322.

Edwards, E. A., Wills, L. E., Reinhard, M., Gribić-Galic, D. Anaerobic degradation of toluene and xylene by aquifer microorganisms and sulfate-reducing conditions, Appl. Environ. Microbiol. 1992, 58, 794-800.

Egli, T., Zehnder, A. J. B., Phosphate and nitrate removal, Curr. Opin. Biotechnol. 1994, 5 , 275- 284.

Elferink, S. J. W. H. O., Visser, A., Pol, L. W. H., Stams, A. J. M., Sulfate reduction in me- 
thanogenic bioreactors, FEMS Microbiol.

Rev. 1994, 15, 119-136.

Filipe, C. D. M., Daigger, G. T., Grady, C. P. L., $\mathrm{pH}$ as a key factor in the competition between glycogen-accumulating and phosphate-accumulating organisms, Water Environ. Res. 2001, 73, 223-232.

Frank, N., Simao-Beaunoir, A. M., Dollard, M. A., Bauda, P., Recombinant plasmid DNA mobilization by activated sludge strains grown in fixed-bed or sequencedbatch reactors, FEMS Microbiol. Ecol. 1996, 21, 139-148.

Fritsche, W., Umwelt-Mikrobiologie. Jena 1998: Gustav Fischer Verlag.

Gensicke, R., Merkel, K., Schuch, R., Winter, J., Biologische Behandlung von Permeaten aus der Ultrafiltration zusammen mit nitrathaltigen Abwässern aus der elektrochemischen Entgratung in submersen Festbettreaktoren, Korrespondenz Abwasser 1998, 1/98, 86-91.

Greiff, K., Leidig, E., Winter, J., Biologische Aufbereitung eines BTEX-belasteten Grundwassers in einem Festbettreaktor, Acta $\mathrm{Hy}$ drochim. Hydrobiol. 1998, 26, 95-103.

Häggblom, M. M., Reductive dechlorination of halogenated phenols by a sulfate-reducing consortium, FEMS Microbiol. Ecol. 1998, 26, 35-41.

Hammes, W., Winter, J., Kandler, O., The sensitivity of pseudomurein-containing genus Methanobacterium to inhibitors of murein synthesis, Arch. Microbiol. 1979, 123, 275-279.

Hanaki, K., Matsuo, T., Nagase, M., Mechanism of inhibition caused by long-chain fatty acids in anaerobic digestion process, Biotechnol. Bioeng. 1981, 23, 1591-1610.

Hansen, T. A., Metabolism of sulfate-reducing prokaryotes, Antonie van Leeuwenhoek 1994, 66, 165-185.

Heald, S. C., Jenkins, R. O., Expression and substrate specificity of the toluene dioxygenase of Pseudomonas putida NCIMB 11767, Appl. Microbiol. Biotechnol. 1996, 45, 56-62. Hellinga, C., Schellen, A. A. J. C., Mulder, J. W., Van Loosdrecht, M. C. M., Heijnen, J. J., The Sharon process: an innovative method for nitrogen removal from ammoniumrich waste water, Water Sci. Technol. 1998, 37, 135-142.

Henze, M., Harremoes, P., Jansen, J., Arvin, E., Wastewater treatment: Biological and
Chemical Processes, 2nd edit. Heidelberg 1997: Springer-Verlag.

Hilpert, R., Winter, J., Hammes, W., Kandler, O., The sensitivity of archaebacteria to antibiotics, Zentralbl. Bakteriol. Mikrobiol. Hyg. (Abt. 1 Orig. C) 1981, 2, 11-20.

Hinchee, R. E., Müller, R. N., Johnson, P. C. (eds.), Bioremediation 3, Vol. 2: In-Situ Aeration, Air Sparging, Bioventing and Related Processes. Columbus, OH 1995a: Battelle Press.

Hinchee, R. E., Vogel, C. M., Brockman, F. J. (eds.), Bioremediation 3, Vol. 8: Microbial Processes for Bioremediation. Columbus, $\mathrm{OH}$ 1995b: Battelle Press.

Hörber, C., Christiansen, N., Arvin, E., Ahring, B. K., Improved dechlorination performance of upflow anaerobic sludge blanket reactors by incorporation of Dehalospirillum multivorans into granular sludge, Appl. Environ. Microbiol. 1998, 64, 1860-1863.

Ianotti, E. L., Kafkewitz, P., Wolin, M. J., Bryant, M. P., Glucose fermentation products of Ruminococcus albus grown in continuous culture with Vibrio succinogenes: changes caused by interspecies transfer of hydrogen, J. Bacteriol. 1973, 114, 1231-1240.

Juteau, P., Beaudet, R., McSween, G., Lépine, F., Milot, S., Bisaillon, J.-G., Anaerobic biodegradation of pentachlorophenol by a methanogenic consortium, Appl. Microbiol. Biotechnol. 1995, 44, 218-224.

Kafkewitz, D., Fava, F., Armenante, P. M., Effect of vitamins on the aerobic degradation of 2-chlorophenol, 4-chlorophenol, and 4-chlorobiphenyl, Appl. Microbiol. Biotechnol. 1996, 46, 414-421.

Kennes, C., Wu, W.-M., Bhathnagar, L., Zeikus, J. G., Anaerobic dechlorination and mineralization of pentachlorophenol and 2,4,6trichlorophenol by methanogenic pentachlorophenol degrading granules, Appl. Microbiol. Biotechnol. 1996, 44, 801-806.

Kerrn-Jespersen, J. P., Henze, M., Biological phosphorus uptake under anoxic and aerobic conditions, Water Res. 1993, 27, 617-624.

Knoll, G., Winter, J., Anaerobic degradation of phenol in sewage sludge: benzoate formation from phenol and $\mathrm{CO}_{2}$ in the presence of hydrogen, Appl. Microbiol. Biotechnol. 1987, 25, 384-391.

Knoll, G., Winter, J., Degradation of phenol via carboxylation to benzoate by a defined, obligate syntrophic consortium of anaerobic bacteria, Appl. Microbiol. Biotechnol. 1989, 30, 318-324. 
Knowles, R., Denitrification, Microbiol. Rev. 1982, 46, 43-70.

Kobayashi, T., Hashinage, T., Mikami, E., Suzuki, T., Methanogenic degradation of phenol and benzoate in acclimated sludges, Water Sci. Technol. 1989, 21, 55-65.

Korda, A., Santas, P., Tenente, A., Santas, R., Petroleum hydrocarbon bioremediation: sampling and analytical techniques, in situ treatments and commercial microorganisms currently used, Appl. Microbiol. Biotechnol. 1997, 48, 677-686.

Krause D. O., Denman S. E., Mackie R. I., Morrison M., Rae A. L., Attwood G. T., McSweeney C. S., Opportunities to improve fiber degradation in the rumen: microbiology, ecology, and genomics, FEMS Microbiology Reviews 2003, 27, 663-693.

Kreysa, G., Wiesner, J. (eds.), In-situ-Sanierung von Böden, Resümee und Beiträge des 11. Dechema-Fachgespräches Umweltschutz. Frankfurt am Main 1996: Dechema, Deutsche Gesellschaft für Chemisches Apparatewesen.

Kristjansson, J. K., Schönheit, P., Thauer, R. K., Different $K_{\mathrm{s}}$ values for hydrogen of methanogenic bacteria and sulfate reducing bacteria: an explanation for the apparent inhibition of methanogenesis by sulfate, Arch. Microbiol. 1982, 131, 278-282.

Krumholz, L. R., Sharp, R., Fishbain, S. S., A freshwater anaerobic coupling acetate oxidation to tetrachloroethene dehalogenation, Appl. Environ. Microbiol. 1996, 62, 4108-4113.

Kuai, L., Verstraete, W., Ammonium removal by the oxygen-limited autotrophic nitrification-denitrification system, Appl. Environ. Microbiol. 1998, 64, 4500-4506.

Kuba, T., Wachtmeister, A., Van Loosdrecht, M. C. M., Heijnen, J. J., Effect of nitrate on phosphorus release in biological phosphorus removal systems, Water Sci. Technol. 1994, 30, 263-269.

Kuenen, J. G., Robertson, L. A., Combined nitrification-denitrification processes, FEMS Microbiol. Rev. 1994, 15, 109-117. Kuo, C.-W., Sharak Genthner, B. R., Effect of added heavy metal ions on biotransformation and biodegradation of 2-chlorophenol and 3-chlorobenzoate in anaerobic bacterial consortia, Appl. Environ. Biotechnol. 1996, 62, 2317-2323.
Lamed, R., Bayer, E. A., The cellulosome of Clostridium thermocellum, Adv. Appl. Microbiol. 1988, 33, 1-46.

Langenhoff, A. A. M., Brouwers-Ceiler, D. L., Engelberting, J. H. L., Quist, J. J., Wolkenfelt, J. G. P. N. et al., Microbial reduction of manganese coupled to toluene oxidation, FEMS Microbiol. Ecol. 1997, 22, 119-127.

Lee, M. J., Zinder, S. H., Isolation and characterisation of a thermophilic bacterium which oxidizes acetate in synthrophic association with a methanogen and which grows acetogenically on $\mathrm{H}_{2} \mathrm{CO}_{2}$, Appl. Environ. Microbiol. 1988, 54, 124-129.

Lens P., Vallero M., Esposito G., Zandvoort M., Perspectives of sulfate reducing bioreactors in environmental biotechnology, Re/Views in Environmental Science and Technology 2002, 1, 311-325.

Leschine, S. B., Cellulose degradation in anaerobic environments, Annu. Rev. Microbiol. 1995, 49, 399-426.

Lloyd, J. R., Microbial reduction of metals and radionuclides, FEMS Microb. Rev. 2003, 27 , 411-425.

Lovley, D. R., Dissimilatory Fe(III) and Mn(IV) reduction, Microbiol. Rev. 1991, 55, 259-387.

Lovley, D. R., Bioremediation of organic and metal contaminants with dissimilatory metal reduction, J. Ind. Microbiol. 1995, 14, 85-93.

Lovley, D. R., Coates, J. D., Bioremediation of metal contamination, Curr. Opin. Biotechnol. 1997, 8, 285-289.

Lovley, D. R., Lonergan, D. J., Anaerobic oxidation of toluene, phenol and $p$-cresol by the dissimilatory iron-reducing organism GS-15, Appl. Environ. Microbiol. 1990, 56, 1858-1864. Lovley, D. R., Phillips, E. J. P., Reduction of chromate by Desulfovibrio vulgaris (Hildenborough) and its $\mathrm{C}_{3}$ cytochrome, Appl. Environ. Microbiol. 1994, 60, 726-728.

Lovley, D. R., Phillips, E. J. P., Gorby, Y. A., Landa, E. R., Microbial reduction of uranium, Nature 1991, 350, 413-416.

Lovley, D. R., Phillips, E. J. P., Lonergan, D. J., Widman, P. K., Fe(III) and $\mathrm{S}^{0}$ reduction by Pelobacter carbinolicus, Appl. Environ. Microbiol. 1995, 61, 2132-2138.

Lui, Y., Energy uncoupling in microbial growth under substrate-sufficient conditions, Appl. Microbiol. Biotechnol. 1998, 49, 500-505. Macy, J. M., Lawson, S., DeMoll-Decker, H., Bioremediation of selenium oxyanions in San Joaquin drainage water using Thauera se- 
lenatis in a biological reactor system, Appl. Microbiol. Biotechnol. 1993, 40, 588-594.

Margesin, R., Schinner, F., Bioremediation of diesel-oil-contaminated alpine soils at low temperatures, Appl. Microbiol. Biotechnol. 1997, 47, 462-468.

Margesin, R., Schinner, F., Low-temperature bioremediation of a waste water contaminated with anionic surfactants and fuel oil, Appl. Microbiol. Biotechnol. 1998, 49, 482-486.

McCartney, D. M., Oleszkiewicz, J. A., Sulfide inhibition of anaerobic degradation of lactate and acetate, Water Res. 1991, 25, 203-209.

McClure, N. C., Weightman, A. J., Fry, J. C., Survival and catabolic activity of natural and genetically engineered bacteria in a laboratory-scale activated sludge unit, Appl. Environ. Microbiol. 1991, 57, 366-373.

McInerney, M. J., Anaerobic hydrolysis and fermentation of fats and proteins, in: Biology of Anaerobic Microorganisms (Zehnder, A. J. B., ed.), pp. 373-415. New York 1988: Wiley.

Megharaj, M., Wittich, R.-M., Blasco, R., Pieper, D. H., Timmis, K. N., Superior survival and degradation of dibenzo- $p$-dioxin and dibenzofuran in soil by soil-adapted Sphingomonas sp. strain RW1, Appl. Microbiol. Biotechnol. 1997, 48, 109-114.

Middeldorp, P. J. M., de Wolf, J., Zehnder, A. J. B., Schraa, G., Enrichment and properties of a 1,2,4-trichlorobenzene-dechlorinating methanogenic microbial consortium, Appl. Environ. Microbiol. 1997, 63, 1225-1229.

Mörsen, A., Rehm, H. J., Degradation of phenol by a mixed culture of Pseudomonas puti$d a$ and Cryptococcus elinovii adsorbed on activated carbon, Appl. Microbiol. Biotechnol. 1987, 26, 283-288.

Mulder, J. W., Van Loosdrecht, M. C. M., Hellinga, C., Van Kempen, R., Full-scale application of the Sharon process for treatment of rejection water of digested sludge dewatering, Water Sci. Technol. 2001, 43, 127-134.

Mutzel, A., Reinscheid, U. M., Antranikian, G., Müller, R., Isolation and characterization of a thermophilic Bacillus strain that degrades phenol and cresols as sole carbon source at $70{ }^{\circ} \mathrm{C}$, Appl. Microbiol. Biotechnol. 1996, 46, 593-596.
Natarajan, M. R., Wu, W.-M., Nye, J., Wang, H., Bhatnagar, L., Jain, M. K., Dechlorination of polychlorinated biphenyl congeners by an anaerobic microbial consortium, Appl. Microbiol. Biotechnol. 1996, 46, 673-677.

Oleszkiewicz, J. A., Mastaller, T., McCartney, D. M., Effects of $\mathrm{pH}$ on sulfide toxicity to anaerobic processes, Environ. Technol. Lett. 1989, 10, 815-822.

Omil, F., Lens, P., Visser, A., Hulshoff, L. W., Lettinga, G., Long-term competition between sulfate reducing and methanogenic bacteria in UASB reactors treating volatile fatty acids, Biotechnol. Bioeng. 1998, 57, 676-685.

Oremland, R. W., Hollibaugh, J. T., Maest, A. S., Presser, T. S., Miller, L. G., Culbertson, C. W., Selenate reduction to elemental selenium by anaerobic bacteria in sediments and culture: biogeochemical significance of a novel, sulfate-independent respiration, Appl. Environ. Microbiol. 1989, 55, 2333-2343.

Örlygsson, J., Houwen, F. P., Svensson, B. H., Thermophilic anaerobic amino acid degradation: deamination rates and end-product formation, Appl. Microbiol. Biotechnol. 1995, 43, 235-241.

Pynaert, K., Barth, F., Smets, F., Beheydt, D., Verstraete, W., Start-up of autotrophic nitrogen removal reactors via sequential biocatalyst addition, Environ. Sci. Technol. 2004, 38, 1228-1235.

Rheinheimer, G., Hegemann, W., Raff, J., Sekoulov, I., Stickstoffkreislaufim Wasser. München 1988: Oldenbourg Verlag.

Robertson, L. A., Kuenen, J. G., Aerobic denitrification: a controversy revived, Arch. Microbiol. 1984, 139, 351-354.

Robertson, L. A., van Niel, W. W. J., Torremans, R. A. M., Kuenen, J. G., Simultaneous nitrification and denitrification in aerobic chemostat cultures of Thiosphera pantotropha, Appl. Environ. Microbiol. 1988, 54, 2812-2818.

Robinson, J. B., Tuovinen, O. H., Mechanisms of microbial resistance and detoxification of mercury and organomercury compounds: physiological, biochemical, and genetic analyses, Microbiol. Rev. 1984, 48, 95-124.

Sanford, R. A., Cole, J. R., Löffler, F. E., Tiedje, J. M., Characterization of Desulfitobacterium chlororespirans sp. nov., which grows by coupling the oxidation of lactate to the reductive dechlorination of 3-chloro-4-hydroxybenzoate, Appl. Environ. Biotechnol. 1996, 62, 3800-3808. 
Schink, B., Energetics of syntrophic cooperation in methanogenic degradation, Microbiol. Mol. Biol. Rev. 1997, 61, 262-280.

Schlegel, H. G., Allgemeine Mikrobiologie, 7th edit. Stuttgart 1992: Georg Thieme Verlag.

Schmidt, I., Sliekers, O., Schmid, M., Cirpus, I., Strous, M., Bock, E., Kuenen, J. G., Jetten, M. S. M., Aerobic and anaerobic ammonia oxidizing bacteria: competitors or natural partners? FEMS Microbiol. Ecol. 2002, 39, 175-181.

Schmidt, I., Sliekers, O., Schmid, M., Bock, E., Fuerst, J., Kuenen, J. G., Jetten, M. S. M., Strous, M., New concepts of microbial treatment processes for the nitrogen removal in wastewater, FEMS Microbiol. Rev. 2003, 27, 481-492.

Schnuerer, A., Schink, B., Svensson, B. H., Clostridium ultunense sp. nov., a mesophilic bacterium oxidizing acetate in synthrophic association with a hydrogenotrophic methanogenic bacterium, Int. J. Syst. Bacteriol. 1996, 46, 1145-1152.

Schön, G., Jardin N., Biological and chemical phosphorus removal. In: Biotechnology, Environmental Processes I (H.-J. Rehm, G. Reed, A. Pühler, P. Stadler, series eds.), Volume 11A (J. Winter ed.) 1999, pp. 285-319 .

Schön, G., Bußmann, M., Geywitz-Hetz, S., Bildung von Lachgas $\left(\mathrm{N}_{2} \mathrm{O}\right)$ im belebten Schlamm aus Kläranlagen, GWF Wasser Abwasser 1994, 135, 293-301.

Selvaratnam, C., Schoedel, B. A., McFarland, B. L., Kulpa, C. F., Application of the polymerase chain reaction (PCR) and the reverse transcriptase/PCR for determining the fate of phenol-degrading Pseudomonas putida ATCC 11172 in a bioaugmented sequencing batch reactor, Appl. Microbiol. Biotechnol. 1997, 47, 236-240.

Seviour, R. J., Mino, T., Onuki, M., The microbiology of biological phosphorus removal in activated sludge systems, FEMS Microbiol. Rev. 2003, 27, 99-127.

Sharma, P. K., McCarty, P. L., Isolation and characterization of a facultatively aerobic bacterium that reductively dehalogenates tetrachloroethene to cis-1,2-dichloroethene, Appl. Environ. Microbiol. 1996, 62, 761-765. Shin, H.-S., Song, Y.-C., A model for evaluation of anaerobic degradation characteristics of organic waste: focusing on kinetics, rate-limiting step, Environ. Technol. 1995, 16, 775-784.
Smith, D. G., Tellurite reduction in Schizosaccharomyces pombe, J. Gen. Microbiol. 1974, 83, 389-392.

Smolders, G. J. F., Van der Meij, J., van Loosdrecht, M. C. M., Heijnen, J. J., Model of the anaerobic metabolism of the biological phos phorus removal process; stoichiometry and pH influence, Biotechnol. Bioeng. 1994, 43, 461-470.

Smolders, G. J. F., van Loosdrecht, M. C. M. Heijnen, J. J., Steady state analysis to evaluate the phosphate removal capacity and acetate requirement of biological phosphorus removing mainstream and sidestream process configurations, Water Res. 1996, 30, 2748-2760.

Speece, R. E., Parkin, G. F., Bhattacharya, S., Takashima, S., Trace nutrient requirements of anaerobic digestion, in: Proc. EWPCA Conf. Anaerobic Treatment, a Grown Up Technology, Amsterdam, Industrial Presentations (Europe) B.V.'s-Gravelandseweg 284-296, Schiedam, The Netherlands 1986, pp. 175-188.

Stams, A. J. M., Metabolic interactions between anaerobic bacteria in methanogenic environments, Antonie von Leeuwenhoek 1994, 66, 271-294.

Stouthamer, A. H., de Boer, A. P. N., van der Oost, J., van Spanning, R. J. M., Emerging principles of inorganic nitrogen metabolism in Paracoccus denitrificans and related bacteria, Antonie von Leeuwenhoek 1997, 71, 33-41. Straub, K. L., Benz, M., Schink, B., Widdel, F., Anaerobic, nitrate-dependent microbial oxidation of ferrous iron, Appl. Environ. Microbiol. 1996, 62, 1458-1460.

Strous, M., Van Gerven, E., Zheng, P., Kuenen, J. G., Jetten, M. S. M., Ammonium removal from concentrated waste streams with the anaerobic ammonium oxidation (Anamox) process in different reactor configurations, Water Res. 1997, 8, 1955-1962.

Thauer, R. K., Jungermann, K., Decker, K., Energy conservation in chemotrophic anaerobic bacteria, Bacteriol. Rev. 1977, 41, 100-180.

Thiele, J. H., Chartrain, M., Zeikus, J. G., Control of interspecies electron flow during anaerobic digestion: role of the floc formation, Appl. Environ. Microbiol. 1988, 54, 10-19. Unz, R. F., Shuttleworth, K. L., Microbial mobilization and immobilization of heavy metals, Curr. Opin. Biotechnol. 1996, 7 , 307-310. 
Valenzuela, J., Bumann, U., Cespedes, R., Padilla, L., Gonzalez, B., Degradation of chlorophenols by Alcaligenes eutrophus JMP134 (pJP4) in bleached kraft mill effluent, Appl. Environ. Microbiol. 1997, 63, 227-232.

Van de Graaf, A. A., Mulder, A., de Bruijn, P., Jetten, M. S. M., Robertson, L. A., Kuenen, J. G., Anaerobic oxidation of ammonium is a biologically mediated process, Appl. Environ. Microbiol. 1995, 61, 1246-1251.

Van de Graaf, A. A., de Bruijn, P., Robertson, L. A., Jetten, M. S. M., Kuenen, J. G., Autotrophic growth of anaerobic, ammoniumoxidizing microorganisms in a fluidized bed reactor, Microbiology 1996, 142, 2187-2196.

Van de Graaf, A. A., de Bruijn, P., Robertson, L. A., Jetten, M. S. M., Kuenen, J. G., Metabolic pathway of anaerobic ammonium oxidation on the basis of ${ }^{15} \mathrm{~N}$ studies in a fluidized bed reactor, Microbiology 1997, 143, 2415-2421.

Van Der Gast, C. J., Whiteley, A. S., Starkey, M., Knowles, C. J., Thompson, I. P., Bioaugmentation strategies for remediating mixed chemical effluents, Biotechnol. Prog. 2003, 19, 1156-1161.

Van Ginkel, C. G., Plugge, C. M., Stroo, C.

A., Reduction of chlorate with various energy substrates and inocula under anaerobic conditions, Chemosphere 1995, 31, 4057-4066.

Van Limbergen, H., Top, E. M., Verstraete, W., Bioaugmentation inactivated sludge: current features and future perspectives, Appl. Microbiol. Biotechnol. 1998, 50, 16-23.

Van Loosdrecht, M. C. M., Jetten, M. S. M., Method for treating ammonia-containing wastewater, Patent PCT/NL97/00482 1997.

Van Loosdrecht, M. C. M., Smolders, G. J., Kuba, T., Heijnen, J. J., Metabolism of microorganisms responsible for enhanced biological phosphorus removal from wastewater, Antonie van Leeuwenhoek 1997a, 71, 109-116.

Van Loosdrecht, M. C. M., Hooijmans, C. M., Brdjanovic, D., Heijnen, J. J., Biological phosphate removal processes, Appl. Microbiol. Biotechnol. 1997b, 48, 289-296.

Vavilin, V. A., Rytov, S. V., Lokshina, L. Y., Two-phase model of hydrolysis kinetics and its application to anaerobic degradation of particulate organic matter, Appl. Biochem. Biotechnol. 1997, 63-65, 45-58.

Wagner, M., Erhart, R., Manz, W., Amman, R., Lemmer, H. et al., Development of an rRNAtargeted oligonucleotide probe specific for the genus Acinetobacter and its application for in situ monitoring in activated sludge, Appl. Environ. Microbiol. 1994, 60, 792-800.

Wallace, W., Ward, T., Breen, A., Attaway, H., Identification of an anaerobic bacterium which reduces perchlorate and chlorate as Wolinella succinogenes, J. Ind. Microbiol. 1996, 16, 68-72.

Warren, R. A. J., Microbial hydrolysis of polysaccharides, Annu. Rev. Microbiol. 1996, 50, 183-212.

White, C., Gadd, G. M., Mixed sulphate-reducing bacterial cultures for bioprecipitation of toxic metals: factorial and response-surface analysis of the effects of dilution rate, sulphate and substrate concentration, Microbiology 1996, 142, 2197-2205.

White, C., Sayer, J. A., Gadd, G. M., Microbial solubilization and immobilization of toxic metals: key biogeochemical processes for treatment of contamination, FEMS Microbiol. Rev. 1997, 20, 503-516.

Whitman, W. B., Bowen, T. L., Boone, D. R., The methanogenic bacteria, in: The Prokaryotes (Balows, A., Trüper, H. G., Dworkin, M., Harder, W., Schleifer, K.-H. (eds.), pp. 719-767. New York 1992: Springer-Verlag.

Widdel, F., Growth of methanogenic bacteria in pure culture with 2-propanol and other alcohols as hydrogen donors, Appl. Environ. Microbiol. 1986, 51, 1056-1062.

Widdel, F., Microbiology and ecology of sulfate- and sulfur-reducing bacteria, in: Biology of Anaerobic Microorganisms (Zehnder, A. J. B., ed.), pp. 469-585. New York 1988: Wiley.

Wild, H. E., Sanyer, C. N., McMahon, T. C., Factors affecting nitrification kinetics, J. Water Pollut. Control Fed. 1971, 43, 1845-1854.

Wildenauer, F. X., Winter, J., Anaerobic digestion of high-strength acidic whey in a $\mathrm{pH}$ controlled up-flow fixed film loop reactor, Appl. Microbiol. Biotechnol. 1985, 22, 367-372. Wildenauer, F. X., Winter, J., Fermentation of isoleucine and arginine by pure and syntrophic cultures of Clostridium sporogenes, FEMS Microbiol. Ecol. 1986, 38, 373-379.

Winter, J., Energie aus Biomasse, Umschau 1983, 25, 26, 774-779. 
Winter, J., Anaerobic waste stabilization, Biotechnol. Adv. 1984, 2, 75-99.

Winter, J. U., Cooney, C. L., Fermentation of cellulose and fatty acids with enrichments from sewage sludge, Eur. J. Appl. Microbiol. Biotechnol. 1980, 11, 60-66.

Winter, J., Zellner, G., Thermophilic anaerobic degradation of carbohydrates: metabolic properties of microorganisms from the different phases, FEMS Microbiol. Rev. 1990, 75, 139-154.

Winter, J., Schindler, F., Wildenauer, F., Fermentation of alanine and glycine by pure and syntrophic cultures of Clostridium sporogenes, FEMS Microbiol. Ecol. 1987, 45, 153-161.

Winter, J., Knoll, G., Sembiring, T., Vogel, P., Dietrich, G., Mikrobiologie des anaeroben Abbaus von Biopolymeren und von aromatischen und halogenaromatischen Verbindungen, in: Biogas: Anaerobtechnik in der Abfallwirtschaft (Thomé-Kozmiensky, K. J., ed.). Berlin 1989: EF-Verlag für Energie und Umweltschutz.

Winter, J., Hilpert, H., Schmitz, H., Treatment of animal manures and wastes for ultimate disposal: review, Asian Aust. J. Anim. Sci. 1992, 5, 199-215.

Winterberg, R., Sahm, H., Untersuchungen zum anaeroben Proteinabbau bei der zweistufigen anaeroben Abwasserreinigung, Lecture: DECHEMA Arbeitsausschuß Umweltbiotechnologie, January 1992.

Wolin, M. J., Interactions between $\mathrm{H}_{2}$-producing and methane-producing species, in: Microbial Formation and Utilization of Gases $\left(\mathrm{H}_{2}, \mathrm{CH}_{4}, \mathrm{CO}\right)$ (Schlegel, H. G., Gottschalk, G., Pfennig, N., eds.), pp. 14-15. Göttingen 1976: Göltze.

Wolin, M. J., Hydrogen transfer in microbial communities, in: Microbial Interactions and Communities, Vol. 1 (Bull, A. T., Slater, J. H., eds.), pp. 323-356. London 1982: Academic.
Wu, M.-W., Nye, J., Hickey, R. F., Jain, M. K., Zeikus, J. G., Dechlorination of PCE and TCE to ethene using anaerobic microbial consortium, in: Bioremediation of Chlorinated Solvents (Hinchee, R. E., Leeson, A., Semprini, L., eds.), pp. 45-52. Columbus, OH 1995 : Battelle Press.

Wu, Q., Bedard, D. L., Wiegel, J., Influence of incubation temperature on the microbial reductive dechlorination of 2,3,4,6-tetrachlorobiphenyl in two freshwater sediments, Appl. Environ. Microbiol. 1996, 62, 4174-4179.

Wu, W. M., Bhatnagar, L., Zeikus, J. G., Performance of anaerobic granules for degradation of pentachlorophenol, Appl. Environ. Microbiol. 1993, 59, 389-397.

Yerushalmi, L., Guiot, S. R., Kinetics of biodegradation of gasoline and its hydrocarbon constituents, Appl. Microbiol. Biotechnol. 1998, 49, 475-481.

Zayed, G., Winter, J., Removal of organic pollutants and of nitrate from wastewater from the dairy industry by denitrification, Appl. Microbiol. Biotechnol. 1998, 49, 469-474.

Zellner, G., Winter, J., Secondary alcohols as hydrogen donors for $\mathrm{CO}_{2}$ reduction by methanogens, FEMS Microbiol. Lett. 1987a, 44, 323-328.

Zellner, G., Winter, J., Analysis of a highly efficient methanogenic consortium producing biogas from whey, Syst. Appl. Microbiol. 1987b, 9, 284-292.

Zellner, G., Bleicher, K., Braun, E., Kneifel, H., Tindall, B. J. et al., Characterization of a new mesophilic, secondary alcohol-utilizing methanogen, Methanobacterium palustre spec. nov. from a peat bog, Arch. Microbiol. 1989, 151, 1-9.

Zumft, W. G., Cell biology and molecular basis of denitrifications, Microbiol. Mol. Biol. Rev. 1997, 61, 533-616. 